NBER WORKING PAPER SERIES

NATIVE INTERNAL MIGRATION AND THE LABOR MARKET IMPACT OF IMMIGRATION

\author{
George J. Borjas \\ Working Paper 11610 \\ http://www.nber.org/papers/w11610 \\ NATIONAL BUREAU OF ECONOMIC RESEARCH \\ 1050 Massachusetts Avenue \\ Cambridge, MA 02138 \\ September 2005
}

Robert W. Scrivner Professor of Economics and Social Policy, Kennedy School of Government, Harvard University; and Research Associate, National Bureau of Economic Research. I am grateful to Alberto Abadie, Richard Freeman, Edward Glaeser, Daniel Hamermesh, Lawrence Katz, Robert Rowthorn, Jonathan Skinner, Stephen Trejo, and two anonymous referees for very helpful comments on an earlier draft, and to the Smith-Richardson Foundation for research support. The views expressed herein are those of the author(s) and do not necessarily reflect the views of the National Bureau of Economic Research.

(C2005 by George J. Borjas. All rights reserved. Short sections of text, not to exceed two paragraphs, may be quoted without explicit permission provided that full credit, including $@$ notice, is given to the source. 
Native Internal Migration and the Labor Market Impact of Immigration

George J. Borjas

NBER Working Paper No. 11610

September 2005

JEL No. J61, R23

\begin{abstract}
This paper presents a theoretical and empirical study of how immigration influences the joint determination of the wage structure and internal migration behavior for native-born workers in local labor markets. Using data from the 1960-2000 decennial censuses, the study shows that immigration is associated with lower in-migration rates, higher out-migration rates, and a decline in the growth rate of the native workforce. The native migration response attenuates the measured impact of immigration on wages in a local labor market by 40 to 60 percent, depending on whether the labor market is defined at the state or metropolitan area level.
\end{abstract}

George J. Borjas

Kennedy School of Government

Harvard University

79 JFK Street

Cambridge, MA 02138

and NBER

gborjas@harvard.edu 


\section{NATIVE INTERNAL MIGRATION AND THE LABOR MARKET IMPACT OF IMMIGRATION}

\section{George J. Borjas*}

\section{Introduction}

Immigrants in the United States cluster in a small number of geographic areas. In 2000, for example, 69.2 percent of working-age immigrants resided in six states (California, New York, Texas, Florida, Illinois, and New Jersey), but only 33.7 percent of natives lived in those states. Similarly, 38.4 percent of immigrants lived in four metropolitan areas (New York, Los Angeles, Chicago, and San Francisco), but only 12.2 percent of natives lived in the four metropolitan areas with the largest native-born populations (New York, Chicago, Los Angeles, and Philadelphia).

Economic theory suggests that immigration into a closed labor market affects the wage structure in that market by lowering the wage of competing workers and raising the wage of complements. Most of the empirical studies in the literature exploit the geographic clustering of immigrants to measure the labor market impact of immigration by defining the labor market along a geographic dimension — such as a state or a metropolitan area. Beginning with Grossman (1982), the typical study relates a measure of native economic outcomes in the locality (or the change in that outcome) to the relative quantity of immigrants in that locality (or the change in

* Robert W. Scrivner Professor of Economics and Social Policy, Kennedy School of Government, Harvard University; and Research Associate, National Bureau of Economic Research. I am grateful to Alberto Abadie, Richard Freeman, Edward Glaeser, Daniel Hamermesh, Lawrence Katz, Robert Rowthorn, Jonathan Skinner, Stephen Trejo, and two anonymous referees for very helpful comments on an earlier draft, and to the SmithRichardson Foundation for research support. 
the relative number). ${ }^{1}$ The regression coefficient, or "spatial correlation," is then interpreted as the impact of immigration on the native wage structure.

There are two well-known problems with this approach. First, immigrants may not be randomly distributed across labor markets. If immigrants tend to cluster in areas with thriving economies, there would be a spurious positive correlation between immigration and wages either in the cross-section or in the time-series. This spurious correlation could attenuate or reverse whatever measurable negative effects immigrants might have had on the wage of competing native workers. ${ }^{2}$

Second, natives may respond to the entry of immigrants into a local labor market by moving their labor or capital to other localities until native wages and returns to capital are again equalized across areas. An inter-region comparison of the wage of native workers might show little or no difference because the effects of immigration are diffused throughout the national economy, and not because immigration had no economic effects.

In view of these potential problems, it is not too surprising that the empirical literature has produced a confusing array of results. The measured impact of immigration on the wage of native workers in local labor markets fluctuates widely from study to study, but seems to cluster around zero. In recent work (Borjas, 2003), I show that by defining the labor market at the national level—which more closely approximates the theoretical counterpart of a closed labor market — the measured wage impact of immigration becomes much larger. By examining the evolution of wages in the 1960-2000 period within narrow skill groups (defined in terms of

1 See also Altonji and Card (1991); Borjas (1987); Card (1990, 2001); LaLonde and Topel (1991); and Schoeni (1997). Friedberg and Hunt (1995) survey the literature.

2 Borjas (2001) argues that income-maximizing immigrants would want to cluster in high-wage regions, helping to move the labor market towards a long-run equilibrium. The evidence indeed suggests that, within education groups, new immigrants tend to locate in those states that offer the highest rate of return for their skills. 
schooling and labor market experience), I concluded that a 10-percent immigrant-induced increase in the number of workers in a particular skill group reduces the wage of that group by 3 to 4 percent.

In this paper, I explore the disparate findings implied by the two approaches by focusing on a particular adjustment mechanism that native workers may use to avoid the adverse impacts of immigration on local labor markets: internal migration. A number of studies already examine if native migration decisions respond to immigration. As with the wage-impact literature, these studies offer a cornucopia of strikingly different findings, with some studies finding strong effects (Filer 1992; and Frey 1995), and other studies reporting little connection (Card 2001; and Kritz and Gurak2001). ${ }^{3}$

This paper can be viewed as an attempt to reconcile two related, but so far unconnected, strands in the immigration literature. I present a theoretical framework that jointly models wage determination in local labor markets and the native migration decision. The theory yields estimable equations that explicitly link the parameters measuring the wage impact of immigration at the national level, the spatial correlation between wages and immigration in local labor markets, and the native migration response. The model clearly shows that the larger the native migration response, the greater will be the difference between the estimates of the national wage effect and the spatial correlation. The model also implies that it is possible to use the spatial correlations to calculate the "true" national impact of immigration as long as one has information on the migration response of native workers.

I use data drawn from all the Census cross-sections between 1960 and 2000 to estimate the key parameters of the model. The data indicate that the measured wage impact of 
immigration depends intimately on the geographic definition of the labor market, and is larger as one expands the size of the market—-from the metropolitan area, to the state, to the Census division, and ultimately to the nation. In contrast, although the measured impact of immigration on native migration rates also depends on the geographic definition of the labor market, these effects become smaller as one expands the size of the market. These mirror-image patterns suggest that the wage effects of immigration on local labor markets are more attenuated the easier that natives find it to "vote with their feet." In fact, the native migration response can account for between 40 to 60 percent of the difference in the measured wage impact of immigration between the national and local labor market levels, depending on whether the local labor market is defined by a state or by a metropolitan area.

\section{Theory}

I use a simple model of the joint determination of the regional wage structure and the internal migration decision of native workers to show the types of parameters that spatial correlations identify, and to determine if these parameters can be used to measure the national labor market impact of immigration. ${ }^{4}$ Suppose that the labor demand function for workers in skill group $i$ residing in geographic area $j$ at time $t$ can be written as:

\footnotetext{
${ }^{3}$ See also Borjas, Freeman, and Katz (1997); Card and DiNardo (2000); Walker, Ellis, and Barff (1992); White and Hunter (1993); White and Liang (1998); and Wright, Ellis, and Reibel (1997).

4 The model is an application of the Blanchard and Katz (1992) framework that analyzes how local labor market conditions respond to demand shocks. It builds on a framework developed by Borjas, Freeman, and Katz (1997, unpublished appendix), and further elaborated in Borjas (1999). The current presentation differs from the earlier iterations in several ways, particularly by incorporating the presence of internal migration flows before the immigrant influx begins and by deriving estimable equations that can be used to identify the key theoretical parameters.
} 


$$
w_{i j t}=X_{i j t} L_{i j t}^{\eta} \text {, }
$$

where $w_{i j t}$ is the wage of workers in cell $(i, j, t) ; X_{i j t}$ is a demand shifter; $L_{i j t}$ gives the total number of workers (both immigrants, $M_{i j t}$, and natives, $N_{i j t}$ ); and $\eta$ is the factor price elasticity (with $\eta<0$ ). It is convenient to interpret the elasticity $\eta$ as the "true" impact that an immigrant influx would have in a closed labor market in the short run, a labor market where neither capital nor native-born labor responds to the increased supply.

Suppose the demand shifter is both time-invariant and region-invariant $\left(X_{i j t}=X_{i}\right)$. This simplification implies that wages for skill group $i$ differ across regions only because the stock of workers is not evenly distributed geographically. ${ }^{5}$ I assume that the total number of native workers in a particular skill group in the national economy is fixed at $\bar{N}_{i}$. It would not be difficult to extend the model to allow for differential rates of growth (across region-skill groups) in the size of the native workforce.

Suppose that $N_{i j,-1}$ native workers in skill group $i$ reside in region $j$ in the pre-immigration period $(t=-1)$. This geographic sorting of native workers does not represent a long-run equilibrium; some regions have too many workers and other regions too few. The regional wage differentials induce a migration response by native workers even prior to the immigrant influx. In particular, region $j$ experiences a net migration of $\Delta N_{i j 0}$ natives belonging to skill group $i$ between $t=-1$ and $t=0$.

\footnotetext{
5 The extension of the model to incorporate differences in the level of the demand curve would be very cumbersome unless the determinants of the regional differences in demand are well specified. The assumption that the demand shifter is time-invariant implies that the immigrant influx will necessarily lower the average wage in the economy. This adverse wage effect could be dampened by allowing for endogenous capital growth (or for capital flows from abroad).
} 
Beginning at time 0, the local labor market (as defined by a particular skill-region cell) receives an influx of $M_{i j t}$ immigrants. The immigrant influx continues in all subsequent periods. A convenient (but restrictive) assumption is that region $j$ receives the same number of immigrants in each year. The annual immigrant influx for a particular skill-region cell can then be represented by $M_{i j}{ }^{6}$

For simplicity, I assume that immigrants do not migrate internally within the United States - they enter region $j$ and remain there. ${ }^{7}$ Natives continue to make relocation decisions, and region $j$ experiences a net migration of $\Delta N_{i j 1}$ natives in period $1, \Delta N_{i j 2}$ natives in period 2 , and so on. The labor demand function in (1) implies that the wage for skill group $i$ in region $j$ at time $t$ is given by: ${ }^{8}$

$$
\log w_{i j t}=\log X_{i}+\eta \log \left[N_{i j,-1}+(t+1) M_{i j}+\Delta N_{i j 0}+\Delta N_{i j 1}+\ldots+\Delta N_{i j t}\right]
$$

which can be rewritten as:

6 The model can incorporate a time-varying immigrant influx to each region as long as the growth rate of the immigrant stock in group $(i, j)$ is constant. It is worth noting, however, that the location decisions of new immigrants may shift over time. In the 1990s, for example, the traditional immigrant gateways of New York and Los Angeles attracted relatively fewer immigrants as the new immigrants began to settle in areas that did not have sizable foreign-born populations; see Funkhouser (2000) and Zavodny (1999).

7 The initial evidence reported in Bartel (1989) and Bartel and Koch (1991) suggested that immigrants had lower rates of internal migration than natives and that the internal migration decisions of immigrants were not as sensitive to regional wage differences, but instead were heavily influenced by the location decisions of earlier immigrant waves. However, more recent evidence reported in Gurak and Kritz (2000) indicates that the interstate migration rate of immigrants is almost as high as that of natives and that immigrant migration decisions are becoming more sensitive to economic conditions in the state of origin; see also Belanger and Rogers (1992) and Kritz and Nogle (1994).

${ }^{8}$ Note that the model assumes the market clears and ignores the participation decision of native workers. However, part of the adjustment mechanism to the immigrant-induced supply shifts may occur through a decline in labor force participation or an increase in unemployment in the native population. The corresponding decline in the number of working natives would attenuate the wage response and reduce the need for native internal migration; see Rowthorn and Glyn (2003) for a related discussion. 


$$
\log w_{i j t} \approx \log w_{i j,-1}+\eta\left[(t+1) m_{i j}+v_{i j 0}+v_{i j 1}+\ldots+v_{i j t}\right], \quad \text { for } t \geq 0
$$

where $m_{i j}=M_{i j} / N_{i j,-1}$, the flow of immigrants in a particular skill group entering region $j$ relative to the initial native stock; and $v_{i j t}=\Delta N_{i j t} / N_{i j,-1}$, the net migration rate of natives. Note that $w_{i j,-1}$ gives the wage offered to workers in group $(i, j)$ in the pre-immigration period.

I assume that the internal migration response of native workers occurs with a lag. For example, immigrants begin to arrive at $t=0$. The demand function in equation (3) implies that the wage response to immigration is immediate, so that wages fall in the immigrant-penetrated regions. The immigrant-induced migration decisions of natives, however, are not observed until the next period. The lagged supply response that describes the native migration decisions is given by:

$$
v_{i j t}=\sigma\left(\log w_{i j, t-1}-\log \bar{w}_{i, t-1}\right)
$$

where $\sigma$ is the supply elasticity, and $\log \bar{w}_{i, t-1}$ is the equilibrium wage (for skill group $i$ ) that will be observed throughout the national economy once all migration responses to the immigrant influx that has occurred up to time $t-1$ have been made. ${ }^{9}$ Income-maximizing behavior on the part of native workers implies that the elasticity $\sigma$ is positive. If $\sigma$ is sufficiently "small," the

\footnotetext{
${ }^{9}$ More precisely, $\log \bar{w}_{i, t-1}=\log \bar{w}_{i,-1}+\eta\left(t m_{i}\right)$, where $m_{i}$ gives the flow of immigrants in skill group $i$ relative to the total number of natives in that skill group. The model implicitly assumes that the native population is large enough (relative to the immigrant stock) to be able to equalize the number of workers across labor markets through internal migration.
} 
migration response of natives may not be completed within one period. ${ }^{10}$ Note that the migration decision is made by forward-looking native workers who compare the current wage in region $j$ to the wage that region $j$ will eventually attain. Therefore, natives have perfect information about the eventual outcome that results from immigration. Workers are not making decisions based on erroneous information (as in the typical cobweb model). Instead, the lags arise because it is difficult to change locations immediately. ${ }^{11}$

As noted above, the existence of regional wage differentials at time $t=-1$ implies that native internal migration was taking place even prior to the beginning of immigration. It is useful to describe the determinants of the net migration flow $v_{i j 0}$. In the pre-immigration period, the equilibrium wage that would be eventually attained in the economy is:

$$
\log \bar{w}_{i,-1}=X_{i}+\eta \log N_{i}^{*},
$$

where $N_{i}^{*}$ represent the number of native workers in skill group $i$ that would live in each region once long-run equilibrium is attained. ${ }^{12}$ The pre-existing net migration rate of native workers is then given by:

10 The migration behavior underlying equation (4) is analogous to the firm's behavior in the presence of adjustment costs (Hamermesh 1993). The staggered native response can be justified a number of ways. The labor market is in continual flux, with persons entering and leaving the market. Because migration is costly, workers may find it optimal to time the lumpy migration decision concurrently with these transitions. Workers may also face constraints that prevent them from taking immediate advantage of regional wage differentials, including various forms of "job-lock" or short-term liquidity constraints.

${ }^{11}$ It may seem preferable to specify the supply function so that natives take into account the expected impact of continued future immigration. In a sense, however, the flow of immigrants $\left(m_{i j}\right)$ is a "sufficient statistic" because I have assumed that the region receives the same number of immigrants in every period.

12 This number equals the total number of natives in a skill group divided by the number of regions. 


$$
v_{i j 0}=\sigma\left(\log w_{i j,-1}-\log \bar{w}_{i,-1}\right)=\eta \sigma \lambda_{i j}
$$

where $\lambda_{i j}=\log \left(N_{i j,-1} / N_{i}^{*}\right)$. By definition, the variable $\lambda_{i j}$ is negative when the initial wage in region $j$ is higher than the long-run equilibrium wage (in other words, there are fewer workers in region $j$ than there will be after all internal migration takes place). Equation (6) then implies that the net migration rate in region $j$ is positive $($ since $\eta<0)$.

Native net migration continues concurrently with the immigrant influx. The mathematical appendix shows that the native net-migration rate can be written as:

$$
v_{i j t}=\eta \sigma(1+\eta \sigma)^{t} \lambda_{i j}+\left[1-(1+\eta \sigma)^{t}\right] m_{i}-\left[1-(1+\eta \sigma)^{t}\right] m_{i j},
$$

where $m_{i}=M_{i} / \bar{N}_{i}$, and $M_{i}$ gives the per-period flow of immigrants in skill group $i$. I assume that the restriction $0<(1+\eta \sigma)<1$ holds throughout the analysis.

The total number of native workers in cell $(i, j, t)$ is then given by the sum of the initial stock $\left(N_{i j,-1}\right)$ and the net migration flows defined by equation (7), or:

$$
\begin{aligned}
\log N_{i j t} & =\log N_{i j,-1}+\left[(1+\eta \sigma)^{t+1}-1\right] \lambda_{i j} \\
& +\left[\frac{t}{t+1}+\frac{(1+\eta \sigma)}{\eta \sigma} \frac{\left[1-(1+\eta \sigma)^{t}\right]}{(t+1)}\right] \tilde{m}_{i t} \\
& -\left[\frac{t}{t+1}+\frac{(1+\eta \sigma)}{\eta \sigma} \frac{\left[1-(1+\eta \sigma)^{t}\right]}{(t+1)}\right] \tilde{m}_{i j t},
\end{aligned}
$$


where $\tilde{m}_{i t}=(t+1) m_{i}$ gives the stock of immigrants with skill $i$ who have migrated as of time $t$ relative to the number of natives with comparable skills; and $\tilde{m}_{i j t}=(t+1) m_{i j}$ gives the relative stock of immigrants with skill $i$ who have migrated to region $j$ as of time $t .{ }^{13}$ The wage for workers in cell $(i, j, t)$ is then given by:

$$
\begin{aligned}
\log w_{i j t} & =\log w_{i j,-1}+\eta\left[(1+\eta \sigma)^{t+1}-1\right] \lambda_{i j} \\
& +\eta\left[\frac{t}{t+1}+\frac{(1+\eta \sigma)}{\eta \sigma} \frac{\left[1-(1+\eta \sigma)^{t}\right]}{(t+1)}\right] \tilde{m}_{i t} \\
& +\eta\left[\frac{1}{t+1}-\frac{(1+\eta \sigma)}{\eta \sigma} \frac{\left[1-(1+\eta \sigma)^{t}\right]}{(t+1)}\right] \tilde{m}_{i j t} .
\end{aligned}
$$

Equations (8) and (9) describe the evolution of $N_{i j t}$ and $w_{i j t}$ for a particular skill group in a local labor market. The first two terms in each equation indicate that the (current) stock of native workers and the (current) wage level depend on pre-existing conditions. The equations also show how the size of the native workforce and wages adjust to the immigrant-induced shifts in supply. In particular, consider the behavior of the coefficients of the region-specific immigration stock variable $\left(\tilde{m}_{i j t}\right)$ in each of these equations. As $t$ grows large, the coefficient in the native workforce regression (which should be negative) converges to -1 , while the coefficient in the wage regression (which should also be negative) converges to zero. Put differently, the longer the time elapsed between the beginning of the immigrant influx and the measurement of the dependent variables, the more likely that native migration behavior has completely neutralized

${ }^{13}$ A tilde above a variable indicates that the variable refers to the stock of immigrants at a particular point in time (rather than the flow). The multiplicative factor used to define the stocks is $(t+1)$ rather than $t$ because the immigrant influx began in period 0 . 
the immigrant-induced local supply shifts and the less likely that the spatial correlation approach will uncover any wage effect on local labor markets.

Equally important, the two coefficients of the region-specific immigrant stock variable provide an intuitive interpretation of how the spatial correlation - that is, the impact of immigration on wages that can be estimated by comparing local labor markets - relates to the factor price elasticity $\eta$ that gives the national wage impact of immigration. In particular, let $\gamma_{N t}$ be the coefficient of the immigrant stock variable in the native workforce equation, and let $\gamma_{W t}$ be the respective coefficient in the wage equation. Equations (8) and (9) then imply that:

$$
\gamma_{W t}=\eta\left(1+\gamma_{N t}\right)
$$

The coefficient $\gamma_{N t}$ approximately gives the number of natives who migrate out of a particular labor market for every immigrant who settles there $\left(\gamma_{N t} \approx \partial N / \partial \tilde{M}_{t}\right) .{ }^{14}$ The factor price elasticity $\eta$ can be estimated by "blowing up" the spatial correlation, where the division factor is the number of natives who do not move per immigrant who enters the country. To illustrate, suppose that the coefficient $\gamma_{N t}$ is -0.5 , indicating that 5 fewer natives choose to reside in the local labor market for every 10 immigrants entering that market. Equation (10) then implies that the spatial correlation that can be estimated by comparing native wages across local labor markets is only half the size of the true factor price elasticity. ${ }^{15}$

${ }^{14}$ In particular, note that $\gamma_{N t}=\partial \log N_{i j t} / \partial \tilde{m}_{i j t}$ and that $\tilde{m}_{i j t}=\tilde{M}_{i j t} / N$, where $N$ is a (fixed) native baseline.

15 It is important to emphasize that the model presented here, although useful from an empirical perspective, is very restrictive. For instance, the model assumes that native workers anticipate the future impact of immigration, but ignores the fact that firms have similar expectations and that the capital stock will adjust in an optimal fashion to the immigrant-induced increase in labor supply, likely dampening the adverse wage effects of 


\section{Empirical Specification}

In the next section, I use data drawn from the 1960-2000 Censuses to estimate the key

parameters of the model. These data provide five observations for $N_{i j t}, w_{i j t}$, and $\tilde{M}_{i j t}$ (one for each

Census cross-section) for labor markets defined by skill groups and geographic regions. The available data, therefore, are not sufficiently detailed to allow me to estimate the dynamic evolution of the native workforce and wage structure as summarized by equations (8) and (9). These equations, after all, have time-varying coefficients for the variable measuring the regionspecific immigrant influx, and these coefficients are highly nonlinear in time. I instead simplify the framework by applying the approximation $(1+x)^{t} \approx(1+x t)$. Equations (8) and (9) can then be rewritten as: ${ }^{16}$

$$
\begin{aligned}
& \log N_{i j t}=\log N_{i j,-1}+\eta \sigma \lambda_{i j}+\eta \sigma\left(t \lambda_{i j}\right)-\eta \sigma \tilde{m}_{i t}+\eta \sigma \tilde{m}_{i j t}, \\
& \log w_{i j t}=\log w_{i j,-1}+\eta^{2} \sigma \lambda_{i j}+\eta^{2} \sigma\left(t \lambda_{i j}\right)-\eta^{2} \sigma \tilde{m}_{i t}+\eta(1+\eta \sigma) \tilde{m}_{i j t} .
\end{aligned}
$$

Equations (11) and (12) can be estimated by stacking the available data on the size of the native workforce, wages, and immigrant stock across skill groups, regions, and time. Many of the regressors in equations (11) and (12) are absorbed by including appropriately defined vectors

immigration and the need for native internal migration to equilibrate the labor market. Similarly, the asymptotic properties of the model result from restrictive assumptions about how the native workforce is distributed across skill groups, the nature of the immigrant inflows, the absence of capital flows, and the shape of the production function. It would be important to determine how these factors alter the interpretation of spatial correlations. Finally, a more complete analysis would explicitly incorporate the assumption that all agents - native workers, immigrants, and firms - have rational expectations about future immigration.

${ }^{16}$ I also use the approximation that $t$ is relatively large so that the ratio $t /(t+1) \approx 1$ and $1 / t \approx 0$; in other words, the wage convergence process has been going on for some time before we observe the data points. 
of fixed effects in the regressions. For example, the inclusion of fixed effects for the various skill-region cells absorbs the vector of variables $\left(N_{i j,-1}, \lambda_{i j}\right)$ in equation (11) and the vector $\left(w_{i j,-1}\right.$, $\left.\lambda_{i j}\right)$ in equation (12). Similarly, interactions between skill and time fixed effects absorb the variable $\tilde{m}_{i t}$ in both equations.

In addition to these fixed effects, the regression models in (11) and (12) suggest the presence of two regressors that vary by skill, region, and time. The first, of course, is the regionspecific measure of the immigrant stock $\left(\tilde{m}_{i j t}\right)$, the main independent variable in any empirical study that attempts to estimate spatial correlations. The second is the variable $\left(t \lambda_{i j}\right)$, which is related to the (cumulative) net migration of natives that would have been observed as of time ( $t-$ 1) had there been no immigration, and also introduces the initial conditions in the labor market into the regression analysis. This variable is not observable. In the empirical work reported below, I proxy for this variable by including regressors giving either a lagged measure of the number of natives in the workforce or the lagged growth rate of the native workforce in the particular labor market.

The regression models in (11) and (12) provide some insight into why there is so much confusion in the empirical literature regarding the link between native internal migration and immigration or between wages and immigration. Even abstracting from the interpretation of the coefficient of the immigrant stock variable (which represent an amalgam of various structural parameters), this coefficient is estimated properly only if local labor market conditions are properly accounted for in the regression specification.

Suppose, for instance, that immigrants enter those parts of the country that pay high wages. If the initial wage is left out of the wage regression, the observed impact of immigration on wages will be too positive, as the immigrant supply variable is capturing unobserved pre- 
existing characteristics of high-wage areas. Similarly, suppose that immigrants tend to enter those parts of the country that also attract native migrants. If the regression equation does not control for the pre-existing migration flow, equation (11) indicates that the impact of immigration on the size of the native workforce will also be too positive. In fact, Borjas, Freeman, and Katz (1997, p. 30) provide a good example of how controlling for pre-existing conditions can actually change the sign of the correlation between net migration and immigration. In particular, they show that the rate of change in the number of natives living in a state is positively correlated with a measure of concurrent immigrant penetration in the crosssection. But this positive correlation turns negative when they add a lagged measure of native population growth into the regression.

The regression models also suggest that the geographic definition of a labor market is likely to influence the magnitude of the measured spatial correlations. In both regressions, the coefficient of the region-specific immigrant stock variable depends on the value of the parameter $\sigma$, the elasticity measuring the native migration response. The spatial correlation estimated in the native workforce regression depends negatively on $\sigma$, while the spatial correlation estimated in the wage regression depends positively on $\sigma$. The supply elasticity will probably be larger when migration is less costly, implying that $\sigma$ will be greater when the labor market is geographically small. ${ }^{17}$ Equations (11) and (12) then imply that the spatial correlation between the size of the native workforce and the immigrant stock variable will be more negative when the model is estimated using geographically smaller labor markets, and that the spatial correlation between

\footnotetext{
${ }_{17}$ Put differently, it is cheaper to migrate across metropolitan areas to escape the adverse affects of immigration than it is to migrate across states or Census divisions.
} 
the wage and the immigrant stock variable will be more negative for larger labor markets. I will show below that the data indeed confirms this mirror-image implication of the theory.

Finally, it is worth stressing that the coefficients of the immigrant stock variable in this linearized version of the two-equation model satisfy the multiplicative property given by equation (10). In sum, the theory provides a useful foundation for linking the results of very different conceptual and econometric frameworks in the study of the economic impact of immigration.

\section{Data and Descriptive Statistics}

The empirical analysis uses data drawn from the 1960, 1970, 1980, 1990, and 2000 Integrated Public Use Microdata Series (IPUMS) of the U.S. Census. The 1960 and 1970 samples represent a 1 percent sample of the population, while the 1980, 1990, and 2000 samples represent a 5 percent sample. ${ }^{18}$ The analysis is initially restricted to the subsample of men aged 18-64, who do not reside in group quarters, are not enrolled in school, and worked in the civilian sector in the calendar year prior to the Census. ${ }^{19} \mathrm{~A}$ person is defined to be an immigrant if he was born abroad and is either a non-citizen or a naturalized citizen; all other persons are classified as natives.

As in my earlier work (Borjas, 2003), I use both educational attainment and work experience to sort workers into particular skill groups. The key idea underlying this classification is that similarly educated workers with very different levels of work experience are unlikely to be perfect substitutes (Welch 1979; Card and Lemieux 2001). I classify the men into four distinct

\footnotetext{
18 The person weights provided in the public use files are used in the calculations.
} 
education groups: workers who are high school dropouts (they have less than twelve years of completed schooling), high school graduates (they have exactly twelve years of schooling), persons who have some college (they have between thirteen and fifteen years of schooling), and college graduates (they have at least sixteen years of schooling).

The classification of workers into experience groups is imprecise because the Census does not provide any measure of labor market experience or of the age at which a worker first enters the labor market. I assume that the age of entry $\left(A_{T}\right)$ into the labor market is 17 for the typical high school dropout, 19 for the typical high school graduate, 21 for the typical person with some college, and 23 for the typical college graduate. The measure of work experience is then given by $\left(\mathrm{Age}-A_{T}\right) \cdot{ }^{20} \mathrm{I}$ restrict the analysis to persons who have between 1 and 40 years of experience. Welch (1979) suggests that workers in adjacent experience cells are more likely to influence each other's labor market opportunities than workers in cells that are further apart. I capture the similarity among workers with roughly similar years of experience by aggregating the data into five-year experience intervals, indicating if the worker has 1 to 5 years of experience, 6 to 10 years, and so on. There are eight experience groups.

A skill group $i$ then contains workers who have a particular level of schooling and a particular level of experience. There are 32 such skill groups in the analysis (four education groups and eight experience groups). Consider a group of workers who have skills $i$, live in

\footnotetext{
19 The analysis uses the information provided by the variable giving the person's labor force status in the survey week to exclude persons in the military.

20 This definition of work experience is reasonably accurate for native men, but surely contains measurement errors when applied to working women, particularly in the earlier cross-sections when the female labor force participation rate was much lower. The definition also does not capture correctly the level of "effective" experience - the number of years of work experience that are valued by an American employer-in the sample of immigrants. Borjas (2003) finds that correcting for this problem does not greatly affect the measured wage impact of immigration.
} 
region $j$, and are observed in calendar year $t$. The $(i, j, t)$ cell defines a particular labor market at a point in time. The immigrant share in this labor market is defined by:

$$
p_{i j t}=\frac{\tilde{M}_{i j t}}{\tilde{M}_{i j t}+N_{i j t}},
$$

where $\tilde{M}_{i j t}$ gives the stock of foreign-born workers in skill group $i$ who have entered region $j$ as of time $t$, and $N_{i j t}$ gives the number of native workers in that cell. The variable $p_{i j t}$ thus measures the fraction of the workforce that is foreign-born in a particular labor market at a particular point in time.

I begin the empirical analysis by describing how immigration affected different labor markets in the past few decades. As indicated earlier, most of the immigrants who entered the United States in the past 40 years have clustered in a relatively small number of states. Figure 1 shows the trends in the immigrant share, by educational attainment, for three groups of states: California, the other main immigrant-receiving states (Florida, Illinois, New Jersey, New York, and Texas), and the rest of the country. Not surprisingly, the largest immigrant-induced supply increase occurred in California for the least-educated workers. By 2000, almost 80 percent of high-school dropouts in California were foreign-born, as compared to only 50 percent in the other immigrant-receiving states, and 20 percent in the rest of the country. Although the scale of the immigrant influx is smaller for high-skill groups, there is still a large disparity in the size of the supply increase across the three areas. In 2000, for example, over a quarter of college graduates in California were foreign-born, as compared to 18 percent in the other immigrantreceiving states, and 8 percent in the rest of the country. 
Figures 2 and 3 continue the descriptive analysis by showing the trends in the immigrant share for some of the specific schooling-experience groups used in the analysis. To conserve space, I only illustrate these profiles for the two education groups most affected by immigration: high school dropouts (Figure 2) and college graduates (Figure 3).

These figures show that there is significant dispersion in the relative size of the immigrant population over time and across experience groups, even when looking at a particular level of education and a particular part of the country. In 1980, for example, the immigration of high school dropouts in California was particularly likely to affect the labor market opportunities faced by workers with around 15 years of experience, where around half of the relevant population was foreign-born. In contrast, only 30 percent of the workers with more than 30 years of experience were foreign born. By 2000, however, over 80 percent of all high school dropouts with 10 to 35 years of experience were foreign-born. These patterns differed in other parts of the country. In the relatively non-immigrant rest of the country, immigration of high school dropouts was relatively rare prior to 1990 , accounting for less than 10 percent of the workers in the relevant labor market. By 2000, however, immigrants made up more than 30 percent of the high school dropouts with 5 to 15 years of experience.

The data summarized in these figures, therefore, suggest that there has been a great deal of dispersion in how immigration affects the various skill groups in different regional labor markets. In some years, it affects workers in certain parts of the region-education-experience spectrum. In other years, it affects other workers. This paper exploits this variation to measure how wages and native worker migration decisions respond to immigration.

Before proceeding to a formal analysis, it is instructive to document that the raw data reveals equally strong differences in the way that natives have chosen to sort themselves 
geographically across the United States. More important, these location choices seem to be correlated with the immigrant-induced supply shifts. Figure 4 illustrates the aggregate trend. As first reported by Borjas, Freeman, and Katz (1997), the share of the native-born population that chose to live in California stopped growing around 1970, at the same time that the immigrant influx began. This important trend is illustrated in the top panel of Figure 4. The data clearly show the relative numbers of native workers living in California first stalling, and eventually declining, as the scale of the immigrant influx increased rapidly. ${ }^{21}$

The middle panel of Figure 4 illustrates a roughly similar trend in the other immigrant states. As immigration increased in these states (the immigrant share rose from about 8 percent in 1970 to 22 percent in 2000), the fraction of natives who chose to live in those states declined slightly, from 26 to 24.5 percent.

Finally, the bottom panel of the figure illustrates the trend in the relatively non-immigrant areas that form the rest of the country. Although immigration also increased over time in this region, the increase has been relatively small (the immigrant share rose from 2.5 percent in 1970 to 7.5 percent in 2000). At the same time, the share of natives living in this region experienced an upward drift, from 64.5 percent in 1970 to 66.5 percent in 2000 . The evidence summarized in Figure 4, therefore, tends to suggest a link between native location decisions and immigration.

This link is also evident at more disaggregated levels of geography and skills. I used all of the Census data available between 1960 and 2000 to calculate for each $(i, j)$ cell the growth rate of the native workforce during each decade (defined as the log of the ratio of the native workforce at the decade's two endpoints) and the corresponding decadal change in the immigrant share. The top panel of Figure 5 presents the scatter diagram relating these decadal changes at

\footnotetext{
${ }^{21}$ Undoubtedly, other factors also account for California's demographic trends in the past twenty years,
} 
the state level after removing decade effects. The plot clearly suggests a negative relation between the growth rate of a particular class of native workers in a particular state and immigration. The bottom panel of the figure illustrates an even stronger pattern when the decadal changes are calculated at the metropolitan area level. In sum, the raw data clearly reveal that the native workforce grew fastest in those labor markets that were least affected by immigration.

Finally, Table 1 provides an alternative way of looking at the data that also links native migration decisions and immigration. Beginning in 1970, the Census contains information not only on the person's state of residence as of the Census date, but also on the state of residence five years prior to the survey. These data can be used to construct net-migration rates for each of the skill groups in each geographic market, as well as in-migration and out-migration rates. (The construction of these rates will be described in detail later in the paper). To easily summarize the basic trends linking migration rates and immigration, I again break up the United States into three regions: California, the other immigrant-receiving states, and the rest of the country. A native worker is then defined to be an internal migrant if he moves across these three regions in the five-year period prior to the Census.

The differential trends in the net-migration rate across the three regions are revealing. Within each education group, there is usually a steep decline in the net migration rate into California, a slower decline in the net migration rate into the other immigrant states, and a slight increase in the net migration rate into the rest of the country. In other words, the net migration of natives fell most in those parts of the country most heavily hit by immigration.

The other panels of Table 1 show that the relative decline in net migration rates in the immigrant-targeted states arises because of both a relative decline in the in-migration rate and a 
relative increase in the out-migration rate. For example, the in-migration rate of native high school dropouts into California fell from 7.6 to 4.0 percent between 1970 and 2000, as compared to a respective increase from 1.8 to 2.5 percent in the rest of the country. Similarly, the outmigration rates of high school dropouts rose from 7.8 to 9.5 percent in California and from 3.6 to 5.6 percent in the other immigrant states, but fell from 1.8 to 1.6 percent in those states least hit by immigration.

\section{Immigration and Wages}

In earlier work (Borjas, 2003), I showed that the labor market impact of immigration at the national level can be estimated by examining the wage evolution of skill groups defined in terms of educational attainment and experience. This section of the paper re-estimates some of the models presented in my earlier paper, and documents the sensitivity of the wage impact of immigration to the geographic definition of the labor market.

I measure the wage impact of immigration using four alternative definitions for the geographic area covered by the labor market. In particular, I assume that the labor market facing a particular skill group is: (1) a closed national labor market, so that the wage impact of immigration estimated at this level of geography presumably measures the factor price elasticity $\eta$ in the model; (2) a labor market defined by the geographic boundaries of the nine Census divisions; (3) a labor market that operates at the state level; or (4) a labor market bounded by the metropolitan area. ${ }^{22}$

\footnotetext{
22 The metropolitan area is defined in a roughly consistent manner across Censuses beginning in 1980 . The analysis conducted at the metropolitan area level, therefore, uses only the 1980-2000 cross-sections and excludes all workers residing outside the identifiable metropolitan areas.
} 
Let $\log w_{i j t}$ denote the mean $\log$ weekly wage of native men who have skills $i$, work in region $j$, and are observed at time $t \cdot{ }^{23}$ I stack these data across skill groups, geographic areas, and Census cross-sections and estimate the model:

$$
\log w_{i j t}=\theta_{W} p_{i j t}+s_{i}+r_{j}+\pi_{t}+\left(s_{i} \times r_{j}\right)+\left(s_{i} \times \pi_{t}\right)+\left(r_{j} \times \pi_{t}\right)+\varphi_{i j t},
$$

where $s_{i}$ is a vector of fixed effects indicating the group's skill level; $r_{j}$ is a vector of fixed effects indicating the geographic area of residence; and $\pi_{t}$ is a vector of fixed effects indicating the time period of the observation. The linear fixed effects in equation (14) control for differences in labor market outcomes across skill groups, regions, and over time. The interactions $\left(s_{i} \times \pi_{t}\right)$ and $\left(s_{j} \times\right.$ $\left.\pi_{t}\right)$ control for secular changes in the returns to skills and in the regional wage structure during the 1960-2000 period. Finally, the inclusion of the interactions $\left(s_{i} \times r_{j}\right)$ implies that the coefficient $\theta_{W}$ is being identified from changes in wages and immigration that occur within skillregion cells.

Note that the various vectors of fixed effects included in (14) correspond to the vectors of fixed effects implied by the estimating equation derived from the model [equation (12)]. The only exception is that (14) also includes interactions between region and Census year. These interactions would clearly enter the theory if demand shocks were allowed to differentially affect regions over time.

The regression coefficients reported in this section come from weighted regressions, where the weight is the sample size used to calculate the mean log weekly wage in the $(i, j, t)$

\footnotetext{
23 The mean log weekly wage for each cell is calculated in the sample of salaried workers who do not reside in group quarters, are not enrolled in school, are in the civilian workforce, and report a positive value for annual earnings, weeks worked, and usual hours worked in the calendar year prior to the Census.
} 
cell. ${ }^{24}$ The standard errors are clustered by skill-region cells to adjust for the possible serial correlation that may exist within cells.

Finally, the specification I use in the empirical analysis uses the immigrant share, $p$, rather than the relative number of immigrants as of time $t, \tilde{m}=\tilde{M} / N$, as the measure of the immigrant-induced supply increase. It turns out that the relation between the various dependent variables and the relative number of immigrants is highly nonlinear, and is not captured correctly by a linear term in $\tilde{m}$. The immigrant share approximates $\log \tilde{m}$, so that using the immigrant share introduces some non-linearity into the regression model. In fact, the wage effects (appropriately calculated) are similar when including either $\log \tilde{m}$ or a second-order polynomial in $\tilde{m}$ as the measure of the immigrant supply shift. ${ }^{25}$

Consider initially the first three columns of Table 2, which present the basic estimates of the adjustment coefficient $\theta_{W}$ obtained from the sample of working men. The first row summarizes the regression results when the geographic reach of the labor market is assumed to encompass the entire nation. ${ }^{26}$ The estimated coefficient is -0.533 , with a standard error of 0.203 . It is easier to interpret this coefficient by converting it to an elasticity that gives the percent

${ }^{24}$ The coefficients of the immigrant share variable are quite similar when the regressions are not weighted.

25 To illustrate, a regression of the log weekly wage on the relative number of immigrants variable $\tilde{m}$ (and all the fixed effects) has a coefficient of -0.160 (with a standard error of 0.082). The same regression on the log of the relative number variable has a coefficient of -0.071 (.027). Evaluated at the mean value of $\tilde{m}$ in $2000(0.172)$, the implied wage elasticity is -0.41 . A regression specification that includes a second-order polynomial in the relative number variable yields coefficients of $-0.558(0.214)$ and $0.298(0.124)$, implying a wage elasticity of -0.45 . The wage elasticity obtained from the immigrant share specification reported in Table 2 is -0.39 . It is evident that the linear specification in $\tilde{m}$ greatly understates the wage impact of immigration.

26 The specification of the national level regression differs slightly from the generic model presented in equation (14). In particular, the regression equation includes the immigrant share variable, fixed effects indicating the skill group, and fixed effects indicating the time period. Because it is impossible to introduce interactions between the skill group and the time period, I instead introduce all two-way interactions between the following three vectors: fixed effects indicating the group's educational attainment, fixed effects indicating the group's labor market experience, and fixed effects indicating the time period. 
change in wages associated with a percent change in labor supply. In particular, define the wage elasticity as:

$$
\frac{\partial \log w}{\partial \tilde{m}}=\frac{\theta_{W}}{(1+\tilde{m})^{2}} .
$$

By 2000, immigration had increased the size of the workforce by 17.2 percent. Equation (15) implies that the wage elasticity — evaluated at the mean value of the relative number of immigrants — can be obtained by multiplying $\theta_{W}$ by 0.73 . The wage elasticity for weekly earnings is then -0.39 (or $-0.532 \times 0.73$ ). Put differently, a 10 percent immigrant-induced supply increase - that is, an immigrant flow that increases the number of workers in a skill group by 10 percent—reduces weekly earnings in that group by almost 4 percent.

Suppose now that the worker's state of residence defines the geographic area encompassed by the labor market. The data then consists of stacked observations on the immigrant share and the mean log weekly wage for cell $(i, j, t)$. The first row of Panel III in Table 2 reports the estimated coefficient of the immigrant share variable when equation (14) is estimated at the state level. The adjustment coefficient is -0.217 , with a standard error of .033 . At the mean immigrant-induced supply shift, the state-level regression implies that a 10 percent increase in supply reduces the native wage by only 1.6 percent, roughly 40 percent of the estimated impact at the national level. Note that the derivative in equation (15) is precisely the wage impact of immigration captured by the region-specific immigrant stock variable in equation (12). In terms of the parameters of the theoretical model, this derivative estimates the product of elasticities $\eta(1+\sigma \eta)$. 
As discussed earlier, the model suggests that the log wage regression—when estimated at the local labor market level—should include a variable that approximately measures the lagged relative number of natives who would have migrated in the absence of immigration. The second row of the panel adds a variable giving the $\log$ of the size of the native workforce 10 years prior to the Census date. ${ }^{27}$ The inclusion of lagged employment does not alter the quantitative nature of the evidence. The adjustment coefficient is $-0.220(0.033)$. Finally, the third row of the panel introduces an alternative variable to control for the counterfactual native migration flow, namely the rate of growth in the size of the native workforce in the 10 -year period prior to the census date. Again, the estimated wage effects are quite similar.

The remaining panels in Table 2 document the behavior of the coefficient $\theta_{W}$ as the geographic boundary of the labor market is either expanded (to the Census division level) or narrowed (to the metropolitan area level). The key result implied by the comparison of the various panels is that the adjustment coefficient grows numerically larger as the geographic reach of the labor market expands. Using the simplest specification in row 1 in each of the panels, for example, the adjustment coefficient is $-0.043(0.025)$ at the metropolitan area level; increases to $-0.217(0.033)$ at the state level; increases further to $-0.274(0.053)$ at the division level; and jumps to $-0.533(0.203)$ at the national level.

Up to this point, I have excluded working women from the analysis because of the inherent difficulty in measuring their labor market experience and classifying them correctly into the various skill groups. Nevertheless, the last three columns of Table 2 replicate the entire analysis using both working men and women in the regression models. The national-level coefficient is almost identical to that obtained when the regression analysis used only working

${ }^{27}$ I used the 1950 Census to calculate the lagged workforce variable pertaining to the skill-region cells 
men. Equally important, the regressions reveal the same clear pattern of a numerically smaller adjustment coefficient as the labor market becomes geographically smaller: from $-0.352(0.061)$ in the division-level regression, to $-0.266(0.037)$ in the state-level regression, to $-0.057(0.024)$ in the regressions estimates at the level of the metropolitan area. The results, therefore, are quite robust to the inclusion of working women.

The theoretical model presented earlier suggests an interesting interpretation for this correlation between the geographic size of the labor market and the measured wage effect of immigration. As the geographic region becomes smaller, there is more spatial arbitrage — due to interregional flows of labor - that tends to equalize opportunities for workers of given skills across regions.

An alternative explanation for the pattern is that the smaller wage effects measured in smaller geographic units may be due to attenuation bias. The variable measuring the immigrant stock will likely contain more measurement errors when it is calculated at more disaggregated levels of geography. As I show in the next section, it is unlikely that attenuation bias can explain the monotonic relation between the adjustment coefficient and the geographic reach of the labor market.

Overall, the evidence seems to indicate that even though immigration has a sizable adverse effect on the wage of competing workers at the national level, the analysis of wage differentials across regional labor markets conceals much of that impact. The remainder of this paper examines if these disparate findings can be attributed to native internal migration decisions. 


\section{Immigration and Internal Migration}

I now estimate a variety of models - closely linked to the theoretical discussion in Section II - to determine if the evolution of the native workforce or the internal migration behavior of natives is related to immigrant-induced supply increases in the respective labor markets.

\section{A. The Size of the Native Workforce}

Consider the following regression model:

$$
\log N_{i j t}=X_{i j t} \beta+\theta_{N} p_{i j t}+s_{i}+r_{j}+\pi_{t}+\left(s_{i} \times \pi_{t}\right)+\left(r_{j} \times \pi_{t}\right)+\left(s_{i} \times r_{j}\right)+\varepsilon_{i j t},
$$

where $X$ is a vector of control variables discussed below. As with the wage regression specified earlier, the various vectors of fixed effects absorb any region-specific, skill-specific, and timespecific factors that affect the evolution of the native workforce in a particular labor market. Similarly, the interactions allow for decade-specific changes in the number of workers in particular skill groups or in particular states caused by shifts in aggregate demand. Finally, the interaction between the skill and region fixed effects implies that the coefficient of the immigrant supply variable is being identified from changes that occur within a specific skill-region grouping. As before, all standard errors are adjusted for any clustering that may occur at the skill-region level. ${ }^{28}$ I again estimate the model using three alternative definitions for the

\footnotetext{
28 The regressions presented in this section are not weighted by the size of the sample used to calculate the dependent variable in a particular skill-region-time cell, as the weight is proportionately identical to the unlogged value of the dependent variable in some of the cross-sections, and differs only slightly in others (due to the presence of sampling weights in the 1990 and 2000 Censuses). A weighted regression is problematic because it introduces a strong positive correlation between the weight and the dependent variable (observations with large values of the dependent variable would mechanically count more in the regression analysis), and errors in the measurement of the
} 
geographic area encompassed by the labor market: a Census division, a state, and a metropolitan area. Table 3 presents alternative sets of regression specifications that show how the immigrantinduced supply shift affects the evolution of the size of the native workforce.

Consider initially the regressions estimated at the state level, reported in the middle panel of the table. The specification in row (1) uses the sample of working men and does not include any variables in the vector $X$. The estimated coefficient of the immigrant share variable is -0.381 , with a standard error of 0.094 . This regression model, therefore, confirms that there is a numerically important and statistically significant negative relation between immigration and the rate of growth of the native workforce at the state level. The coefficient is easier to interpret by calculating the derivative $\partial N / \partial \tilde{M}$, which gives the change in the size of the native workforce when the stock of immigrant workers increases by one. It is easy to show that the derivative of interest is:

$$
\frac{\partial N}{\partial \tilde{M}}=\frac{\theta_{N}}{(1+\tilde{m})^{2}}
$$

As before, the derivative in equation (17) can be evaluated at the mean value of the immigrant supply increase by multiplying the regression coefficient $\theta_{N}$ by 0.73 . The simplest specification reported in Panel II of Table 3 implies that 2.8 fewer native workers chose to live in a particular state for every 10 additional immigrants entering that state. In terms of the theoretical model, equation (11) implies that the derivative reported in (17) estimates the product of elasticities $\eta \sigma$.

dependent variable would be amplified by the weighting scheme. This type of non-classical measurement error, which has not been appreciated sufficiently in previous studies, imparts a positive bias on the adjustment coefficient in equation (16). In fact, a weighted regression of the state-level specification reported in row 1 of Table 3 leads to an adjustment coefficient of -0.135 (0.094). 
The next two rows of the middle panel of Table 3 estimate more general specifications of the regression model. As noted earlier, I adjust for pre-existing migration flows by including either the lagged log of the number of native workers or the lagged rate of growth in the size of the native workforce. ${ }^{29}$ I also include variables measuring the mean log weekly wage and the unemployment rate in the labor market (again measured at the state level). ${ }^{30}$ These additional variables control for factors that, in addition to immigration, motivate income-maximizing native workers to move from one market to another.

Rows 2 and 3 yield very similar results, so the evidence is not sensitive to which variable is chosen to proxy for the lagged size of native net migration in the absence of immigration. Not surprisingly, lagged measures of the size of the native workforce or its growth rate have a positive impact on the current number of native workers. Similarly, the mean log wage has a positive (sometimes insignificant) coefficient, while the unemployment rate has a negative effect. The coefficient of the immigrant share variable falls to around -0.27 in the most general specification. ${ }^{31}$ This estimate implies that around 2 fewer native workers choose to reside in a particular state for every 10 additional immigrants who enter that state.

The final two rows of the middle panel add the population of working women to the regression analysis. These regressions, in effect, examine the evolution of the entire workforce for a particular labor market defined by skills and region. The inclusion of women in this type of

\footnotetext{
29 To avoid re-introducing the dependent variable on the right-hand-side, the regressions presented in this section use the lagged growth rate of the native workforce 10 to 20 years prior to the Census date. For example, the lagged growth rate for the observation referring to high school graduates in Iowa in 1980 would be the growth rate in the number of high school graduates in Iowa between 1960 and 1970. This definition of the lagged growth rate implies that the regression models using this specification do not include any cells drawn from the 1960 Census.

30 The mean log weekly wage and unemployment rate for each cell are calculated from the data available in each Census cross-section.
} 
regression model could be problematic because of the possibility that many women may be tied movers or tied stayers, so that their location decisions may crucially depend on factors (such as family composition and the distribution of skills within the family) that are ignored in the study. Nevertheless, the state-level regressions suggest that, at least qualitatively, the inclusion of women barely alters the results. The coefficients of the immigrant share variable are not only negative and statistically significant, but are also roughly similar to the ones estimated in the sample of working men.

The other panels of Table 3 re-estimate the regression models at the census division and metropolitan area levels. The estimated impact of the immigrant supply variable typically has the wrong sign at the division level, but with large standard errors. In contrast, the adjustment coefficient is very negative (and statistically significant) at the metropolitan area level. The obvious conclusion to draw by comparing the three panels of the table is that the negative impact of the immigrant share variable gets numerically stronger the smaller the geographic boundaries of the labor market. In the general specification reported in row 2 for working men, for example, the estimated coefficient of the immigrant share variable is $0.055(0.121)$ at the Census division level; $-0.281(0.081)$ at the state level; and $-0.839(0.091)$ at the metropolitan area level. ${ }^{32}$ The coefficient of the metropolitan area regression, in fact, implies that 6.1 fewer native workers choose to reside in a particular metropolitan area for every 10 additional immigrants who enter that locality.

\footnotetext{
31 The coefficient would be virtually identical if both the lagged level and growth rate of the native workforce were included in the regression.

32 The metropolitan area regressions cannot be estimated with the lagged growth rate because that would then leave only one cross-section with sufficient data to estimate the model.
} 
It is worth noting that the geographic variation in the observed spatial correlation between the size of the native workforce and immigration is an exact mirror image of the geographic variation in the spatial correlation between wages and immigration reported in Table 2. As implied by the model, the wage effects are larger when the impact of immigration on the size of the native workforce is weakest (at the Census division level); and the wage effects are weakest when the impact of immigration on the size of the native workforce is largest (at the metropolitan area level).

It would seem as if this mirror-image pattern is not consistent with an attenuation hypothesis: more measurement error for data estimated at smaller geographic units would lead to smaller coefficient estimates at the metropolitan area level in both Tables 2 and 3. There is, however, one possible source of measurement error that could potentially explain the mirrorimage pattern. In particular, note that the adjustment coefficient $\theta_{N}$ estimated by equation (16) may suffer from division bias. The dependent variable appears (in transformed form) as part of the denominator in the immigrant share variable. If the size of the native workforce were measured with error, the division bias would lead to downward-biased estimates of the adjustment coefficient. One could argue that such measurement error would be more severe at the metropolitan area level than in larger geographic regions.

I show below, however, that division bias does not play a central role in generating the mirror-image pattern of coefficients in Tables 2 and 3. Instead, the mirror-image pattern revealed by the two tables provides some support for the hypothesis that there is indeed a behavioral response by the native population that is contaminating the measured wage impact of immigration on local labor markets. 


\section{B. Migration Rates}

Since 1970 the census contains detailed information on the person's state of residence five years prior to the census, and since 1980 there is similar information for the metropolitan area of residence. These data, combined with the information on geographic location at the time of the census, can be used to compute in-, out-, and net-migration rates for native workers in the various skill-region groups. I now examine how these native migration rates respond to the immigrant influx. Therefore, the results presented in this section, which examine the flows of actual native movers, can be interpreted as providing independent confirmation of the findings presented above that link the evolution of the size of the native workforce to the immigrant influx.

To illustrate the calculation of the net migration rate, consider the data available at the state level in a particular census. The worker is an out-migrant from the "original" state of residence (that is, the state of residence five years prior to the survey) if he lives in a different state by the time of the census. The worker is an in-migrant into the current state of residence if he lived in a different state five years prior to the census. I define the in-migration and outmigration rates by dividing the total number of in-migrants or out-migrants in a particular skillstate-time cell by the relevant workforce in the baseline state. ${ }^{33}$ The net migration rate is then defined as the difference between the in-migration and the out-migration rate. To make the results in this section comparable to those reported in Table 3, I multiply all the migration rates by two - this adjustment converts the various rates into decadal changes (which was the unit of change implicitly used in the native workforce regressions).

\footnotetext{
33 The baseline state is the original state of residence when calculating out-migration rates and the current state of residence when calculating in-migration rates. Let $N_{a}$ be the number of native workers in the baseline state (in a particular skill group) five years prior to the Census, and let $N_{b}$ be the number of workers in the same state at the time of the Census. The denominator of the in- and out-migration rates is then given by $\left(N_{a}+N_{b}\right) / 2$.
} 
I concluded the presentation of the theoretical model in Section II by deriving estimable equations that related the size of the native workforce and the native wage to the immigrant supply shift. This section uses a variation of the model with a different dependent variable. Equation (7) gives the expression for the net migration rate for cell $(i, j, t)$. By using the approximation that $(1+x)^{t} \approx 1+x t$, the equation determining the net-migration rate, $v_{i j t}$, can be rewritten as:

$$
v_{i j t}=\eta \sigma \lambda_{i j}+(\eta \sigma)^{2}\left(t \lambda_{i j}\right)-\eta \sigma \tilde{m}_{i t}+\eta \sigma \tilde{m}_{i j t} .
$$

As before, the regression model that I actually use to analyze how migration rates respond to immigration is:

$$
y_{i j t}=X_{i j t} \beta+\theta_{N} p_{i j t}+s_{i}+r_{j}+\pi_{t}+\left(s_{i} \times \pi_{t}\right)+\left(r_{j} \times \pi_{t}\right)+\left(s_{i} \times r_{j}\right)+\varepsilon_{i j t},
$$

where $y_{i j t}$ represents the net-migration, in-migration, or out-migration rate for cell $(i, j, t)$. Note that the coefficient of the region-specific immigrant share variable $\theta_{N}$ identifies the product of elasticities $\eta \sigma$.

Table 4 summarizes the evidence. To conserve space, I only report the general specification that includes all of the variables in the vector $X$. Consider initially the regression results reported for the sample of working men in Panel II, where the dependent variable is the net migration rate estimated at the state level. Because the dependent variable in this regression model measures a change in the native population, I use the lagged native employment growth 
rate as a preferred way of controlling for pre-existing conditions. ${ }^{34}$ The estimated coefficient of the immigrant share variable in the net migration regression is -0.284 , with a standard error of 0.064. As before, this coefficient is more easily interpretable by multiplying it by 0.73 , indicating that 2.1 fewer native workers (on net) move to a particular state for every 10 immigrants who enter that state. It is worth noting that the estimated product of elasticities $\eta \sigma$ is very similar to the corresponding estimate reported in Table 3, when the dependent variable was the log of the size of the native workforce.

Rows 2 and 3 of the middle panel show that the effect of immigration on net migration rates arises both because immigration induces fewer natives to move into the immigrantpenetrated labor markets, and because immigration induces more natives to move out of those markets. The coefficient of the immigrant share variable in the in-migration regression is -0.151 (0.042), while the respective coefficient in the out-migration regression is $0.133(0.049)$. In rough terms, an influx of 10 immigrants into a state's workforce induces 1 fewer native worker to migrate there and encourages 1 native worker already living there to move out.

Finally, the last row in the middle panel replicates the net migration rate regression in the sample of workers that includes both men and women. The adjustment coefficient is negative and significant $(-0.232$, with a standard error of 0.057$)$. As before, the inclusion of women into the analysis does not fundamentally change the results.

The top and bottom panels of Table 4 reproduce the earlier finding that the negative impact of immigration on native migration rates is numerically larger as the geographic area that encompasses the labor market becomes smaller. In the sample of working men, the estimated

\footnotetext{
34 The use of the lagged native employment variable (instead of the lagged employment growth rate) would lead to very similar coefficients. In the state-level regressions, for example, the analogous specification to that reported in row 1 of the middle panel yields a coefficient of $-0.291(0.064)$.
} 
coefficient of the immigrant share variable on the net migration rate is $-0.076(0.046)$ at the division level; $-0.284(0.064)$ at the state level; and $-0.396(0.086)$ at the metropolitan area level. ${ }^{35}$ The evidence, therefore, again suggests that natives find it much easier to respond to immigration by voting with their feet when the geographic area is relatively small, and that this response is attributable to both fewer in-migrants and more out-migrants.

More importantly, this mirror image pattern-relative to the respective pattern in the spatial correlations between wages and immigration — cannot be attributed to measurement error or division bias. After all, both the dependent variable (the net migration rate) and the independent variable (the immigrant share) have a measure of the year $t$ native workforce in the denominator. If the size of the native workforce were measured with error, the division bias would now induce a positive bias in the adjustment coefficient $\theta_{N}$. It seems plausible to argue that this bias would be most severe at the metropolitan area level—where the adjustment coefficient (although not as negative as the respective coefficient in Table 3) is still negative and numerically large. In short, the mirror-image pattern in the spatial correlations that is evident when comparing Tables 2 and 4, cannot be solely attributed to measurement error. It seems to be the result of a systematic behavioral response by native workers that helps to attenuate the wage impact of immigration on local labor markets.

\section{Sensitivity of the Evidence}

As suggested by the descriptive evidence summarized earlier, the regression results reported in Tables 3 and 4 consistently reveal a numerically sizable and statistically significant

\footnotetext{
35 The inclusion of the lagged native workforce variable in the metropolitan area regressions implies that the regressions can only include the 1990 and 2000 cross-sections, as the 1970 Census does not contain the required information.
} 
relation between native migration decisions and immigration. I have already shown that the results are unchanged when women are included in the analysis. I now examine whether the results are also robust to other major specification changes.

Table 5 summarizes the sensitivity experiments that I conducted on the various regression models. To conserve space, the table reports the coefficients of the immigrant share variables estimated at the state level from the size-of-workforce and net migration regressions. For convenience, the top row of the table reproduces the "baseline" results obtained in the sample of working men that has been the focus of the discussion up to this point.

I have used a 5-year experience aggregation to define the various skill groups. Although this classification attempts to capture the insight that workers with roughly the same level of experience are more likely to be perfect substitutes, the choice of the aggregation interval is arbitrary. The results, however, are robust to different classification schemes. Row 2 of Table 5 reports the estimated coefficients when experience groups are defined in terms of 10-year groupings (1-10 years of experience, 11-20 years, and so on). The table clearly indicates that the coefficient of the immigrant share in all of the regressions is quite similar to that reported in the baseline specification.

Similarly, the very different nature of the migration behavior of native workers who have just completed their schooling or who are about to retire might be confounding the underlying correlations. Row 3 of the table re-estimates the basic model (once again returning to the 5 -year experience classification), but excludes workers who have fewer than 5 or more than 35 years of work experience. This specification of the model leads to regression coefficients that are quite similar to those reported in the baseline specification (though somewhat smaller in magnitude). 
As I showed earlier, the state of California has played a central role in the resurgence of large-scale immigration in the past few decades. California has atypical labor market characteristics; it is a very large state with historically high native net-migration rates, a relatively high-skill workforce, and a huge immigrant influx. These characteristics could contaminate many of the results presented above. It is important, therefore, to determine if the sign or magnitude of the estimated coefficients are driven by the outlying observations that describe the outcomes for specific skill groups in California. Row 4 of Table 5 re-estimates the baseline regression models in the subsample of skill-state-year cells that excludes all the California observations. Remarkably, despite the demographic importance of California, there is very little change in the regression coefficients: the adjustment coefficient in either the size-ofworkforce or the net migration rate regressions still hovers around -0.3 .

As I showed earlier, many of the outlying skill-region (in terms of the size of the immigrant influx) likely contain workers who are high school dropouts, and the determinants of the migration behavior of native high school dropouts may differ substantially from that of native workers with higher levels of educational attainment. ${ }^{36}$ It is important, therefore, to assess the sensitivity of the results to the presence of these outlying observations. Row 5 re-estimates the model using the subsample of workers who have at least 12 years of schooling (so there are now only 3 education groups in the analysis). The coefficient of the immigrant share variable in the native workforce regression becomes even more negative (-0.97, with a standard error of 0.18$)$

\footnotetext{
36 Many studies, including some of the classic articles in the economics of internal migration, analyze the strong positive correlation between migration propensities and education (Sjaastad 1962; Ladinksy 1967; and the survey by Greenwood 1997). The analysis in this paper assumes that the elasticity measuring the marginal response of immigrant-induced supply increases to native migration propensities is the same for all skill groups. The inclusion of skill-specific fixed effects throughout the regression analysis, however, allows the various groups to differ in their migration propensities.
} 
when the high school dropouts are excluded from the sample, but the coefficient in the net migration regression is stable at around -0.28 .

Finally, row 6 reports an equally interesting exercise when we redefine the high school dropout category to include only those workers who have between 9 and 11 years of schooling. In 2000, 22.1 percent of immigrants had 8 or fewer years of schooling. It is doubtful that these very low-skill immigrants are competing in the same labor market as the native high school dropouts, 80 percent of whom have between 9 and 11 years of schooling. To analyze the sensitivity of the results to this potential mismatch within the high school dropout category, I simply omitted from the study any workers who have 8 or fewer years of schooling. The high school dropout category, therefore, now is composed entirely of workers who have 9 to 11 years of schooling. The last row of Table 5 shows that the coefficient of the immigrant share variable in the size-of-workforce regression is large and negative, while the coefficient in the netmigration rate regression still hovers at -0.3 .

In sum, the sensitivity experiments summarized in this section show that major changes in the specification of the regression models do not alter the qualitative (and often quantitative) nature of the evidence. Immigrant-induced increases in labor supply are associated with lower native net migration rates, lower in-migration rates, higher out-migration rates, and a smaller growth rate in the size of the native workforce in the affected labor markets.

It is important to emphasize that there is a striking contrast between the robustness of the evidence summarized here and the evidence reported in prior studies. The nature of the link between native internal migration and immigration has attracted a great deal of attention in both the economics and geography literatures. A number of studies, led by Filer (1992), Frey (1995, 1996), Frey et al. (1996), and White and Hunter (1993), reported evidence consistent with a 
"demographic balkanization" of natives and immigrants: natives respond to immigration by moving to areas that had not been affected by immigration. Subsequent studies, including those of Wright, Ellis, and Reibel (1997), White and Imai (1994), Card and DiNardo (2000), Card (2001), and Kritz and Gurak (2001), presented opposing evidence that questioned the demographic importance of this presumed relation. It should be noted, however, that the studies differ greatly in the time periods analyzed, in sample design, in definitions of the geographic region, and in the methodological framework (see the survey-like discussion in Kritz and Gurak, 2001, pp. 133-135). As a result, it is difficult to determine exactly why there is so much dispersion in the evidence across studies.

The empirical analysis presented in this paper differs from the existing literature in three distinct ways. First, the study is strongly embedded in a theoretical framework that emphasizes the importance of netting out pre-existing conditions when attempting to measure the nature of the link between native migration and immigration. As I noted earlier, there is evidence that the sign of the correlation between native migration and immigration can easily switch depending on how a particular study controls for pre-existing conditions (Borjas, Freeman, and Katz, 1997). To illustrate, some states have been long-time recipients of native internal migrants. These states may also have become important gateways for new immigrants, thus introducing a spurious positive correlation between native net migration and immigration. The correct measure of the impact of immigration on native migration would then depend on how the net migration rate of natives into these states changed relative to what it was in the pre-immigration regime.

The current study uses a far longer panel of data than other studies in the literature, many of which have used a single census cross-section to uncover what is undoubtedly a relation that has a crucial time dimension. Card (2001) and Kritz and Gurak (2001), for example, estimate 
correlations using data exclusively from the 1990 census. Although it is unclear what such crosssection correlations actually measure, it is evident that they do not measure the parameters of interest in the context of a dynamic model of native location decisions. The use of a forty-year panel that includes repeated observations on the location decision of native workers and immigrant-induced supply increases experienced by specific groups allows the empirical analysis to net out the long-run trends that undoubtedly characterize internal migration flows for particular groups or particular regions, and thus helps to isolate the impact of immigration.

Second, I emphasize the common-sense (though obviously restrictive) notion that income-maximizing natives will respond to immigration only if their economic opportunities are affected. The immigration of one particular skill group will likely affect the earnings of that skill group more than the earnings of other groups, and one would expect a corresponding differential effect on native migration rates. The empirical study presented here defined skill groups in terms of years of education and work experience - and it is partly this narrower focus on the composition of the skill groups affected by large-scale immigration that allows me to measure a consistent correlation that seems to have been missed by some of the earlier studies.

Finally, my analysis builds on the strong theoretical implication that there exists a systematic relation between the wage structure, native migration decisions, and immigrationand that the nature of this relation is closely linked to the geographic reach of the labor market. The empirical confusion on the nature of the correlation between native migration decisions and immigration is not unique in the immigration literature. As noted earlier, there is an equally confusing set of results contained in the studies that attempt to estimate the labor market impact of immigration by correlating wages in the local labor market and measures of immigrant penetration (see Borjas, 2003, for a discussion). The analysis presented here argues that the 
empirical confusion in these two seemingly unrelated literatures is, in fact, intimately linked. In an important sense, this paper attempts to reconcile the diverse set of findings in two literatures that have not been closely linked before: the impact of immigration on wages and the impact of immigration on native location decisions.

\section{Synthesis}

The theoretical model presented in Section II suggests that the national wage effect of migration and the spatial correlations estimated between wages and immigration across local labor markets are linked through a parameter that measures the native migration response. I now examine whether the large difference actually estimated in Section III in the wage impacts for different geographic definitions of the labor market can be "explained" by the impact of immigration on native location decisions.

Table 6 summarizes the key results of the study. The first row of the table reports that the wage effect at the national level was estimated to be -0.389 (or the coefficient of -0.533 in Table 2 times 0.73 ). I assume that the national labor market approximates the concept of a closed economy, so that this coefficient estimates the factor price elasticity $\eta \cdot{ }^{37}$ The theoretical model presented in this paper implies that the estimated wage effect of immigration will not equal this factor price elasticity whenever the corresponding wage regression is estimated using observations on local labor markets where natives can respond to immigration by moving across markets. The spatial correlation will be numerically smaller, and the gap between the spatial correlation and the true factor price elasticity should reflect the native migration effect.

\footnotetext{
${ }^{37}$ Put differently, I assume that the supply elasticity $\sigma=0$ at the national level.
} 
Row 2 of Table 6 summarizes the estimated migration effects reported earlier (again multiplied by 0.73$).{ }^{38}$ This row, therefore, reports the value of the derivative $\gamma_{N}=\partial N / \partial \tilde{M}$. These migration responses allow me to predict what the spatial correlations should be by using the multiplicative property of the model summarized in equation (10). In particular, let $\gamma_{W}=\partial \log w / \partial \tilde{m}$, the wage effect of immigration at a particular geographic level. The theory then predicts that the spatial correlation between wages and immigration, $\hat{\gamma}_{W}$, is given by:

$$
\hat{\gamma}_{W}=\eta\left(1+\gamma_{N}\right) .
$$

Row 3 of Table 6 uses this equation to mechanically predict the spatial correlations that should be observed if the only adjustment mechanism contaminating the estimation procedure was the internal migration of native workers. To illustrate, consider the migration response revealed by the simplest specification of the size-of-workforce regression at the state level. This regression implies that $\gamma_{N}=-0.278$. The theory then implies that the wage elasticity estimated by relating native wages across states and immigration should be -0.28 (or $-0.389 \times(1-0.278)$ ), roughly a cut of one-quarter in the estimated national wage effect. At the metropolitan area level, the migration response is quite large, implying that the spatial correlation between wages and immigration measurable at the metropolitan area level should be -0.17 . If I instead use the migration responses estimated in the net migration regressions, the predicted spatial correlations are -0.31 and -0.28 at the state and metropolitan area levels, respectively.

\footnotetext{
38 The estimated effects for the size of the native workforce are drawn from rows 1 and 2 of Table 3, and row 1 of Table 4.
} 
Finally, row 4 of Table 6 reports the actual spatial correlations estimated in the data (and first reported in Table 2). At the state level, the wage impact of immigration is around -0.16 . The evidence summarized in Table 6, therefore, indicates that the internal migration response of native workers accounts for about 40 percent of the gap between the wage effects estimated at the state level and at the national level. At the metropolitan area level, the data indicate that the native internal migration response may account for as much as 60 percent of the difference.

This synthesis fails to explain the difference between the national wage effect and the spatial correlation between wages and immigration estimated at the Census division level. It may well be that Census divisions are not an economically meaningful analogue to a labor market. It is also the case that much of the migration that takes place in the United States is within divisions. Between 1995 and 2000, for example, 11.6 percent of the working-age population migrated across metropolitan areas; 9.4 percent migrated across states; and only 6.8 percent migrated across divisions. The use of division-level data, therefore, is probably masking a great deal of the native migration response to immigrant-induced supply shifts.

\section{Summary}

The empirical literature that attempts to estimate the labor market impact of immigration faces an important puzzle. Studies that examine how immigration alters economic opportunities across local labor markets tend to find that immigration has a negligible impact on the wage of competing native workers, while studies that examine how immigration alters economic opportunities at the national level tend to find substantial wage effects. This paper presented a theoretical and empirical analysis of one possible adjustment mechanism that can explain the disparate findings: the internal migration decisions made by native workers. 
The theoretical model presented in this paper illustrates how native migration flows diffuse the impact of immigration across the entire economy, making it difficult to measure the "true" wage impact of immigration by comparing conditions across local labor markets. More importantly, the theory provides a framework that explicitly links the parameters measuring the national wage effect of immigration, the spatial correlation estimated across local labor markets, and the impact of immigration on native migration decisions.

The empirical analysis used data drawn from the 1960-2000 decennial Censuses. The evidence indicates that native internal migration decisions are sensitive to immigrant-induced increases in labor supply. The native population in a particular skill group grew slowest in those parts of the country that experienced the largest immigrant influx. This native supply response is evident both in terms of a decline in native in-migration and an increase in native out-migration. The net native migration response is sizable: for every 10 immigrants who enter a particular state two fewer natives choose to live in that state. The response is even larger at the metropolitan area level: for every 10 immigrants who choose to enter a particular metropolitan area between 3 and 6 natives will choose not to live in that locality.

These migration responses are sufficiently large to explain an important part of the disparate findings obtained in studies that estimate the wage effects of immigration at the national and local labor market levels. At the state level, the native migration response explains about 40 percent of the gap in wage effects. At the metropolitan area level, the migration response may explain as much as 60 percent of the gap.

Naturally, labor markets adjust to immigration in many other ways. Although native migration can explain a good part of the adjustment mechanism, it is likely that flows of goods or 
capital are also important ingredients in the story. The magnitude, economic significance, and labor market consequences of those flows are yet to be determined. 


\section{Mathematical Appendix}

To simplify the mathematical derivations, it is useful to start with a simpler version of the immigrant influx, a one time supply increase. In particular, $M_{i j 0}$ immigrants enter region $j$ at time 0 . Native migration will then occur for two reasons: a response to the initial disequilibrium, and a response to the impact of immigrants on the wage structure. It is useful to consider these two responses separately. As a result of the initial disequilibrium, equation (6) in the text shows that $v_{i j \mathrm{o}}=\eta \sigma \lambda_{i j}$. By solving the model recursively, it follows that $v_{i j t}=\eta \sigma(1+\eta \sigma)^{t} \lambda_{i j}$.

The native response to the one-time immigrant supply increase will depend on the geographic sorting of immigrants relative to the geographic sorting of the native population. Suppose region $j$ has (in the pre-immigration regime) a fraction $q_{i j}$ of the native population in skill group $i$ and receives a fraction $\rho_{i j}$ of the immigrants in that skill group. The region-specific supply increase is then given by:

(A-1) $\quad m_{i j 0}=\frac{M_{i j 0}}{N_{i j 0}}=\frac{\rho_{i j} M_{i}}{q_{i j} N_{i}}=k_{i j} m_{i}$,

where $k_{i j}=\rho_{i j} / q_{i j}$, a measure of the penetration of immigrants into region $j$ relative to the region's pre-immigration size (for a particular skill group). Immigration is distributed neutrally if $k_{i j}=1$.

The impact of the one-time immigrant supply on native migration can be solved recursively. In particular, the supply increase induces $\eta \sigma\left(k_{i j}-1\right) m_{i}$ natives to move in period 1 , 
$\eta \sigma(1+\eta \sigma)\left(k_{i j}-1\right) m_{i}$ in period 2, and $\eta \sigma(1+\eta \sigma) t\left(k_{i j}-1\right) m_{i}$ in period $t$. Combining both sources of native migration flows, the native net migration rate in year $t$ is then given by:

$$
v_{i j t}=\eta \sigma(1+\eta \sigma)^{t} \lambda_{i j}-\eta \sigma(1+\eta \sigma)^{t-1}\left(1-k_{i j}\right) m_{i} .
$$

I assume that $0<(1+\eta \sigma)<1$.

The total (or cumulative) net migration rate of natives at time $t$ is then given by:

$$
\begin{aligned}
V_{i j t} & =\sum_{\tau=0}^{t} \eta \sigma(1+\eta \sigma)^{\tau} \lambda_{i j}-\sum_{\tau=1}^{t} \eta \sigma(1+\eta \sigma)^{\tau-1}\left(1-k_{i j}\right) m_{i} \\
& =\left[(1+\eta \sigma)^{t}-1\right] \lambda_{i j}+\left[1-(1+\eta \sigma)^{t}\right]\left(1-k_{i j}\right) m_{i} .
\end{aligned}
$$

The model can now be more easily extended to the case where the immigrant influx continues indefinitely. The last term of equation (A-3), call if $Y_{i j t}$, gives the (cumulative) net migration rate of natives as of time $t$ induced by a period- 0 immigrant supply increase. Consider now what the native response would be to a similarly-sized supply increase occurring at $t=1$. The net migration rate of natives induced by the period- 1 migration flow would be $Y_{i j, t-1}$. The total net migration of natives in period $t$ attributable to a supply increase of $k_{j j} m_{i}$ in region $j$ between periods 0 and $t-1$ is then given by:

(A-4) $\quad V_{i j t}^{*}=\left[(1+\eta \sigma)^{t}-1\right] \lambda_{i j}+\sum_{\tau=0}^{t-1} Y_{i j t}=\left[(1+\eta \sigma)^{t}-1\right] \lambda_{i j}+\left[t+\frac{(1+\eta \sigma)}{\eta \sigma}\left[1-(1+\eta \sigma)^{t}\right]\right]\left(1-k_{i j}\right) m_{i}$.

Equation (7) in the text can be obtained by differencing (A-4). In particular: 
$(\mathrm{A}-5)$

$$
v_{i j t}=V_{i j t}^{*}-V_{i j, t-1}^{*}=\eta \sigma(1+\eta \sigma)^{t} \lambda_{i j}+\left[1-(1+\eta \sigma)^{t}\right]\left(1-k_{i j}\right) m_{i} .
$$

Equation (7) follows directly by noting that $k_{i j} m_{i}=m_{i j}$. Equations (8) and (9) can be derived by substituting (A-4) in both the equation that determines the current size of the workforce in a particular labor market and in the labor demand function. 


\section{References}

Altonji, Joseph G., and David Card. 1991. "The Effects of Immigration on the Labor Market Outcomes of Less-Skilled Natives." In Immigration, Trade, and the Labor Market, ed. John M. Abowd and Richard B. Freeman, 201-34. Chicago: University of Chicago Press.

Bartel, Ann P. 1989. "Where Do the New U.S. Immigrants Live?” Journal of Labor Economics 7(4):371-91.

Bartel, Ann P. and Marianne J. Koch. 1991. "Internal Migration of U.S. Immigrants.” In Immigration, Trade, and the Labor Market, ed. John M. Abowd and Richard B. Freeman, 12134. Chicago: University of Chicago Press.

Belanger, Alain and Andrei Rogers. 1992. "The Internal Migration and Spatial Redistribution of the Foreign-Born Population in the United States, 1965-70 and 1975-80." International Migration Review 26(4):1342-69.

Blanchard, Olivier Jean and Lawrence F. Katz. 1992. "Regional Evolutions." Brookings Papers on Economic Activity (1):1-75.

Borjas, George J. 1987. "Immigrants, Minorities, and Labor Market Competition." Industrial and Labor Relations Review 40(3):382-92.

Borjas, George J. 1999. “The Economic Analysis of Immigration.” In Handbook of Labor Economics, Vol. 3A, ed. Orley C. Ashenfelter and David Card, 1697-1760. Amsterdam: Elsevier.

Borjas, George J. 2001. "Does Immigration Grease the Wheels of the Labor Market?" Brookings Papers on Economic Activity (1):69-119.

Borjas, George J. 2003. "The Labor Demand Curve Is Downward Sloping: Reexamining the Impact of Immigration on the Labor Market." Quarterly Journal of Economics 118(4):133574 .

Borjas, George J., Richard B. Freeman, and Lawrence F. Katz. 1997. "How Much Do Immigration and Trade Affect Labor Market Outcomes?" Brookings Papers on Economic Activity (1):1-67.

Card, David. 1990. "The Impact of the Mariel Boatlift on the Miami Labor Market." Industrial and Labor Relations Review 43(2):245-57.

Card, David. 2001. "Immigrant Inflows, Native Outflows, and the Local Labor Market Impacts of Higher Immigration." Journal of Labor Economics 19(1):22-64.

Card, David and John DiNardo. 2000. "Do Immigrant Inflows Lead to Native Outflows?" American Economic Review 90(2):360-67. 
Card, David, and Thomas Lemieux. 2001. "Can Falling Supply Explain the Rising Return to College for Younger Men? A Cohort-Based Analysis." Quarterly Journal of Economics 116(2):705-46.

Filer, Randall K. 1992. "The Impact of Immigrant Arrivals on Migratory Patterns of Native Workers." In Immigration and the Work Force: Economic Consequences for the United States and Source Areas, ed. George J. Borjas and Richard B. Freeman, 245-69. Chicago: University of Chicago Press.

Frey, William H. 1995. "Immigration and Internal Migration 'Flight' from U.S. Metro Areas: Toward a New Demographic Balkanization.” Urban Studies 32(4-5):733-57.

Frey, William H., Kao Lee Liaw, Yu Xie, and Marcia J. Carlson. 1996. "Interstate Migration of the U.S. Poverty Population: Immigration 'Pushes' and White Magnet 'Pulls'.' Population and Environment 17(6):491-533.

Friedberg, Rachel M., and Jennifer Hunt. 1995. "The Impact of Immigration on Host Country Wages, Employment and Growth." Journal of Economic Perspectives 9(2):23-44.

Funkhouser, Edward. 2000. "Changes in the Geographic Concentration and Location of Residence of Immigrants.” International Migration Review 34(2): 489-510.

Greenwood, Michael. 1997. "Internal Migration in Developed Countries.” In Handbook of Population and Family Economics, Volume 1B, ed. Mark R. Rosenzweig and Oded Stark, 647-720. Amsterdam: Elsevier.

Grossman, Jean Baldwin. 1982. "The Substitutability of Natives and Immigrants in Production." Review of Economics and Statistics 54(4):596-603

Gurak, Douglas T. and Mary M. Kritz, 2000. "The Interstate Migration of U.S. Immigrants: Individual and Contextual Determinants.” Social Forces 78(3):1017-39.

Hamermesh, Daniel. 1993. Labor Demand. Princeton: Princeton University Press.

Kritz, Mary M. and Douglas T. Gurak. 2001. "The Impact of Immigration on the Internal Migration of Natives and Immigrants." Demography 38(1):133-45.

Kritz, Mary M. and June Marie Nogle. 1994. "Nativity Concentration and Internal Migration among the Foreign-Born.” Demography 31(3):509-24.

LaLonde, Robert J., and Robert H. Topel. 1991. "Labor Market Adjustments to Increased Immigration." In Immigration, Trade, and the Labor Market, ed. John M. Abowd and Richard B. Freeman, 167-99. Chicago: University of Chicago Press. 
Ladinsky, Jack. 1967. "The Geographic Mobility of Professional and Technical Manpower.” Journal of Human Resources 2(4):475-94.

Rowthorn, Robert and Andrew Glyn. 2003. "Convergence and Stability in U.S. Regional Employment.” Department of Economics Discussion Paper Series, No. 92. Oxford: Oxford University.

Schoeni, Robert F. 1997. "The Effect of Immigrants on the Employment and Wages of Native Workers: Evidence from the 1970s and 1980s." Santa Monica, CA: The RAND Corporation.

Sjaastad, Larry A. 1962. "The Costs and Returns of Human Migration." Journal of Political Economy 70(Supplement):80-93

Walker, Robert, Mark Ellis, and Richard Barff. 1992. "Linked Migration Systems: Immigration and Internal Labor Flows in the United States." Economic Geography 68(3):234-38.

Welch, Finis. 1979. "Effects of Cohort Size on Earnings: The Baby Boom Babies' Financial Bust." Journal of Political Economy 87(5, Part 2):S65-S97.

White, Michael J. and Hunter, Lori. 1993. "The Migratory Response of Native-Born Workers to the Presence of Immigrants in the Labor Market." Providence, RI: Brown University.

White, Michael J. and Zai Liang, 1998. "The Effect of Immigration on the Internal Migration of the Native-Born Population, 1981-1990." Population Research And Policy Review 17(2):141-66.

Wright, Richard A., Mark Ellis, and Michael Reibel. 1997. "The Linkage between Immigration and Internal Migration in Large Metropolitan Areas in the United States." Economic Geography 73(2):234-54.

Zavodny, Madeline. 1999. "Determinants of Recent Immigrants' Locational Choices." International Migration Review 33(4):1014-30. 
Figure 1. The immigrant share of the male workforce, by education and area of country

High school dropouts

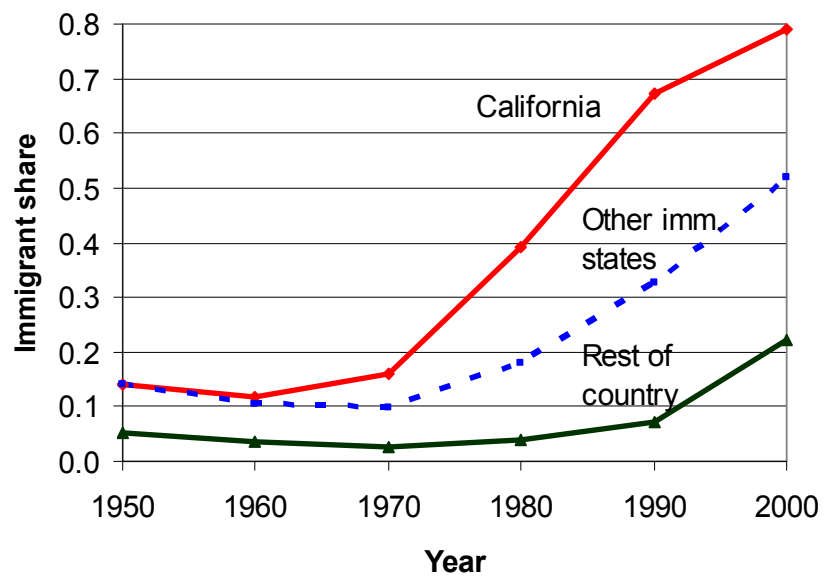

Some college

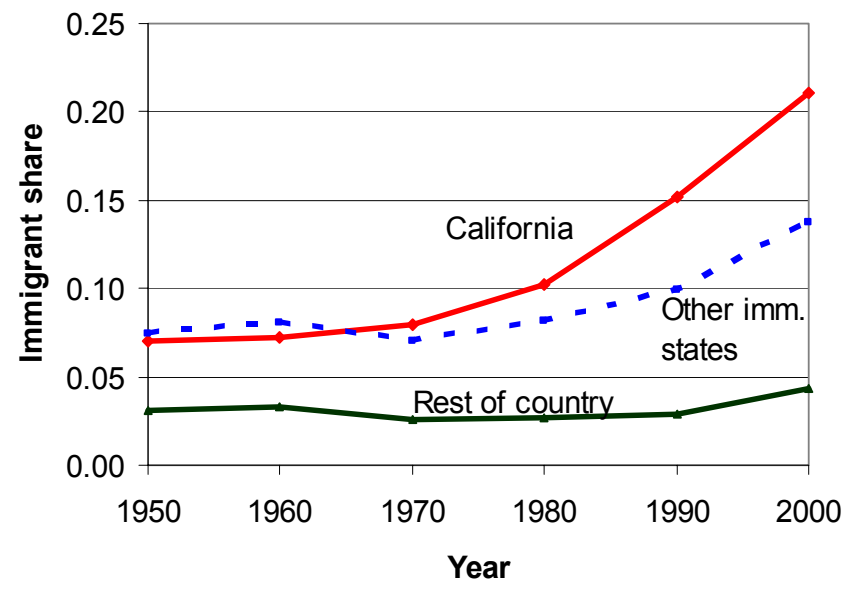

High school graduates

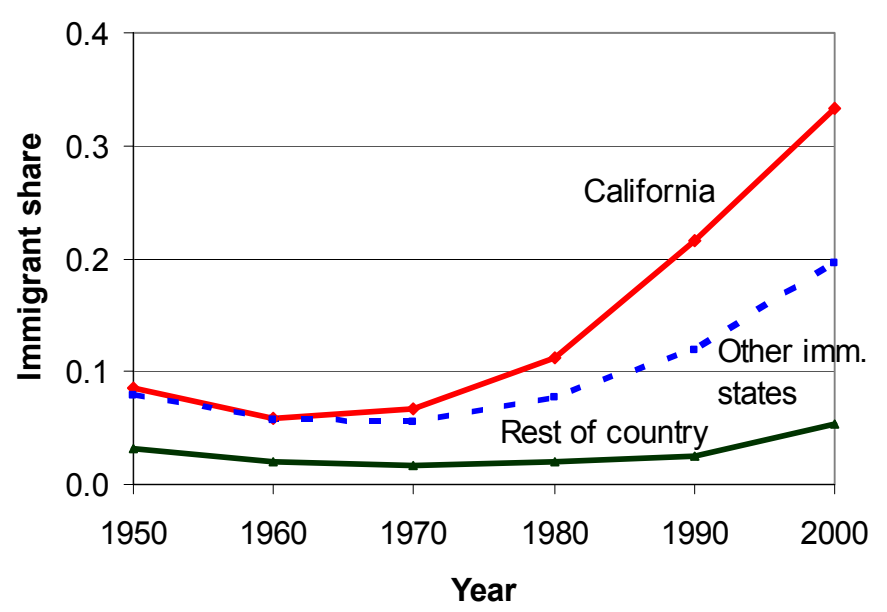

College graduates

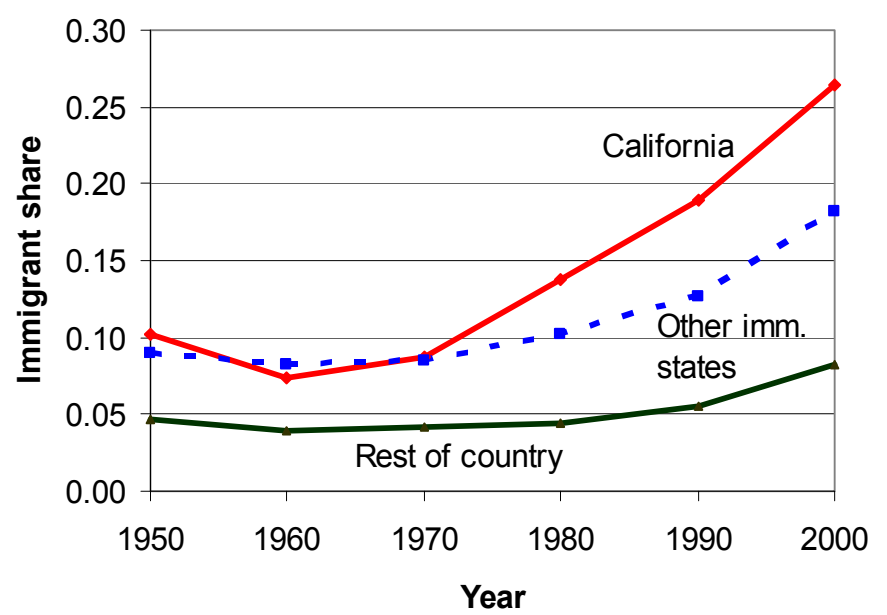

Note: The “other immigrant states" include Florida, Illinois, New Jersey, New York, and Texas. 
Figure 2. Immigrant share for high school dropouts, by years of work experience

\section{A. California}

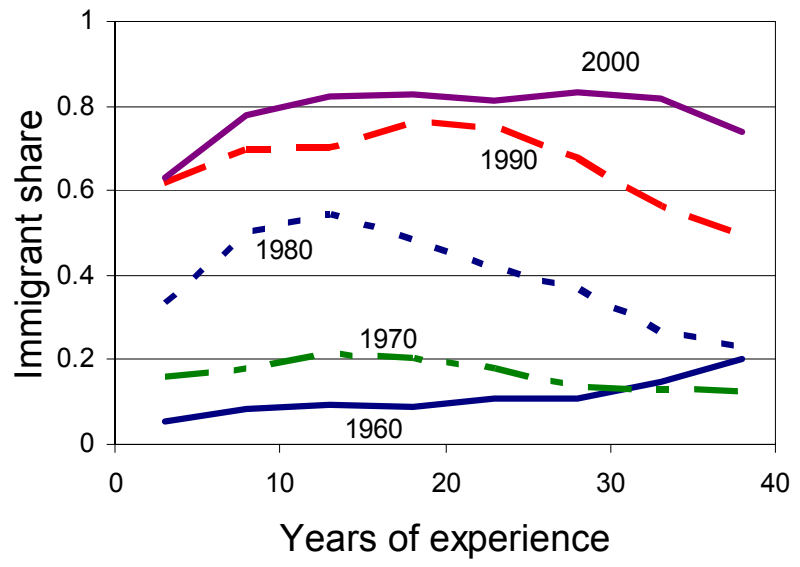

\section{B. Other immigrant states}

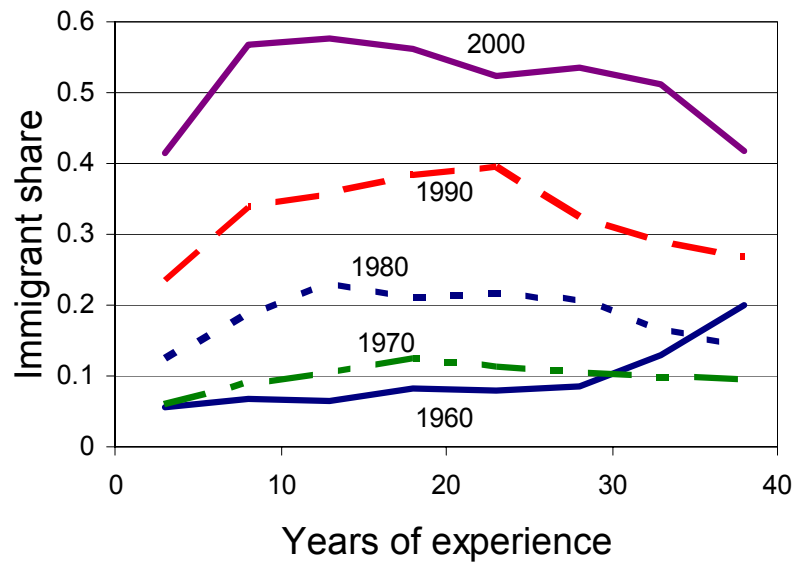

\section{Rest of the country}

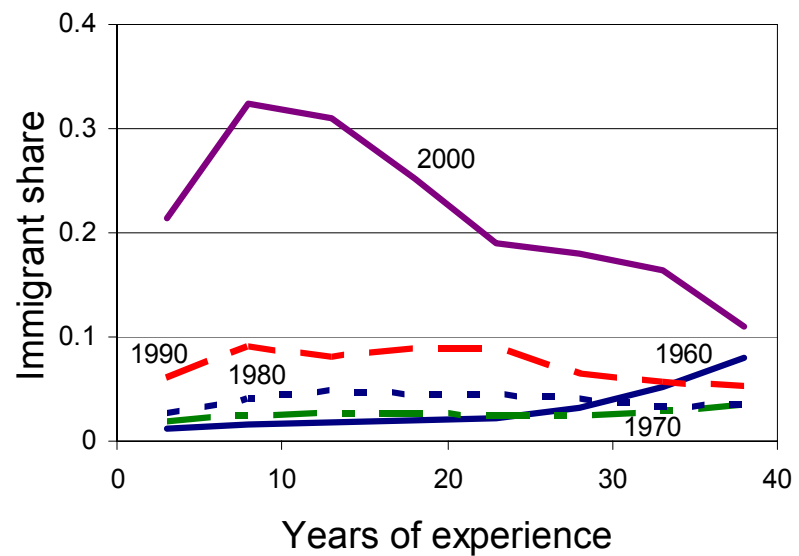

Note: The "other immigrant states" include Florida, Illinois, New Jersey, New York, and Texas. 
Figure 3. Immigrant share for college graduates, by years of work experience

\section{A. California}

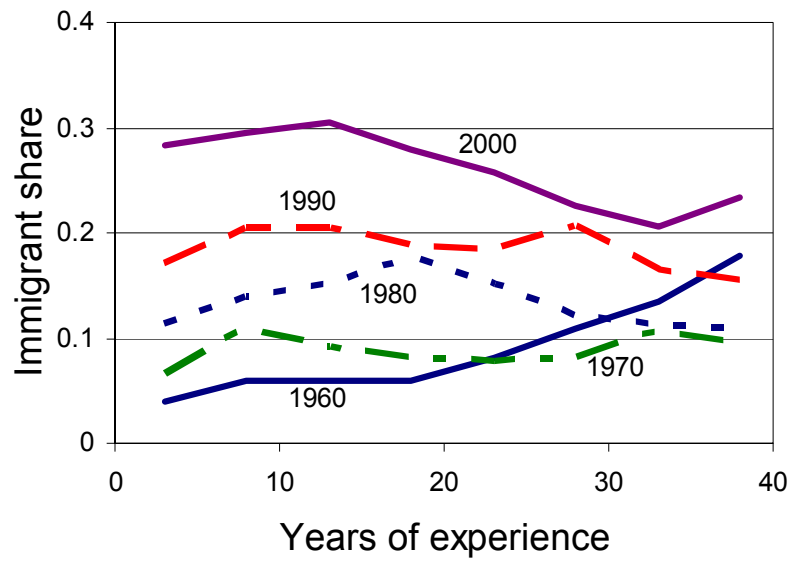

B. Other immigrant states

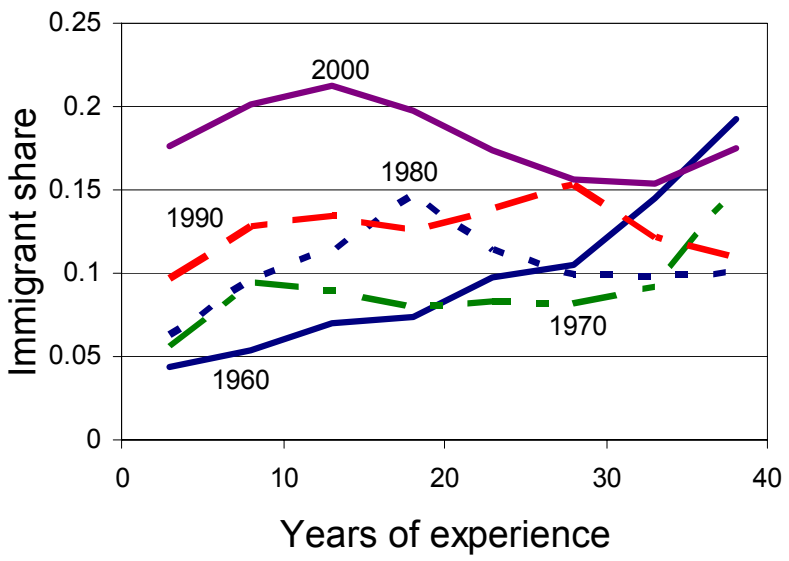

\section{Rest of the country}

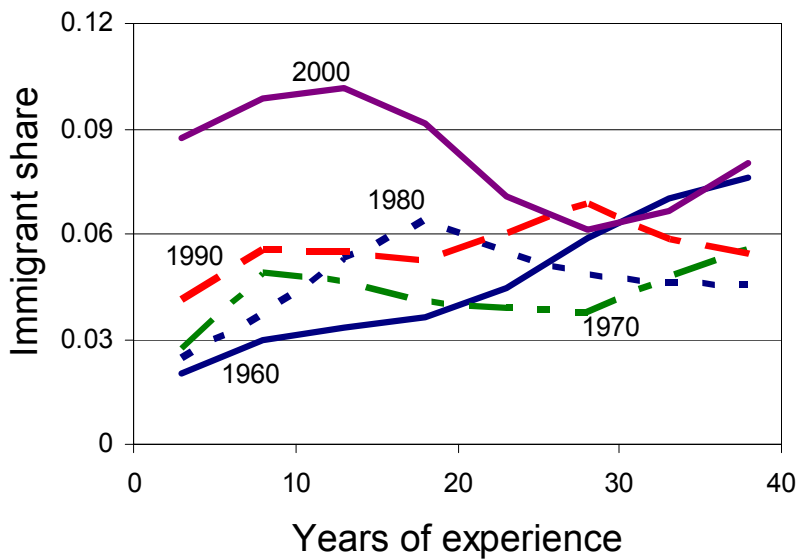

Note: The "other immigrant states" include Florida, Illinois, New Jersey, New York, and Texas. 
Figure 4. Geographic sorting of native workforce and immigration

\section{A. California}

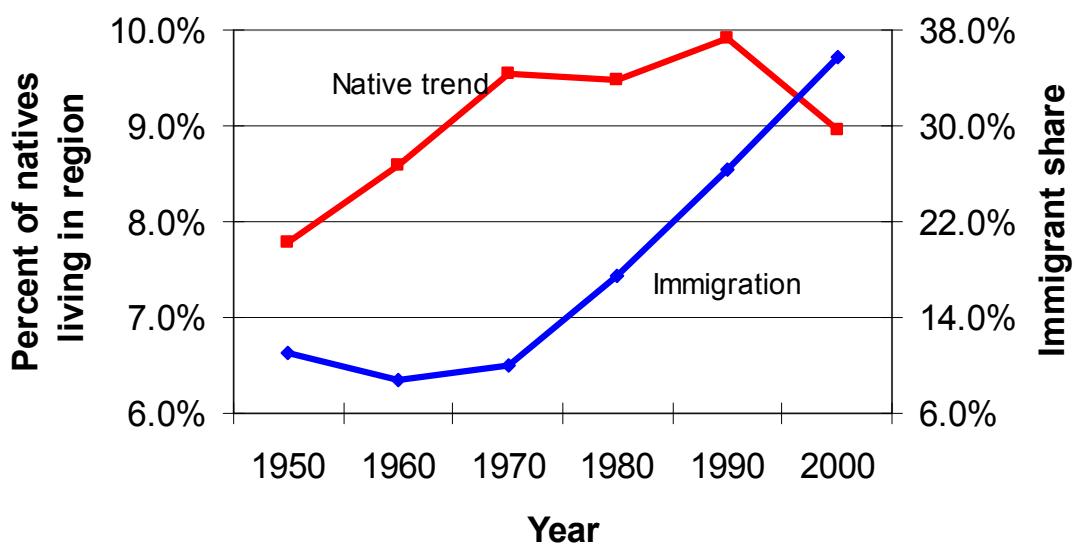

\section{B. Other immigrant states}

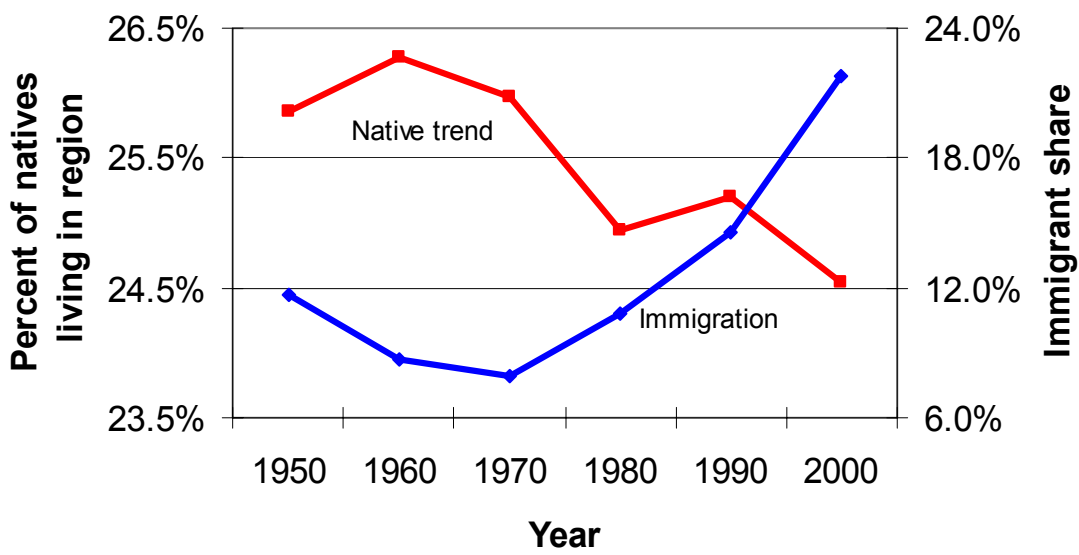

\section{Rest of the country}

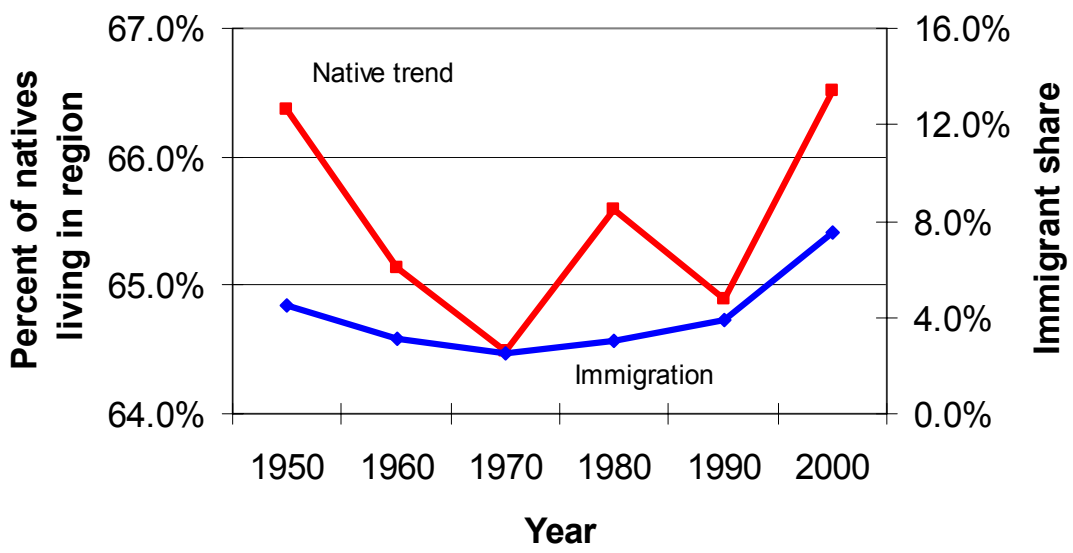

Note: The "other immigrant states" include Florida, Illinois, New Jersey, New York, and Texas. 
Figure 5. Scatter diagram relating the growth rate of the native workforce and immigration

\section{A. State level data}

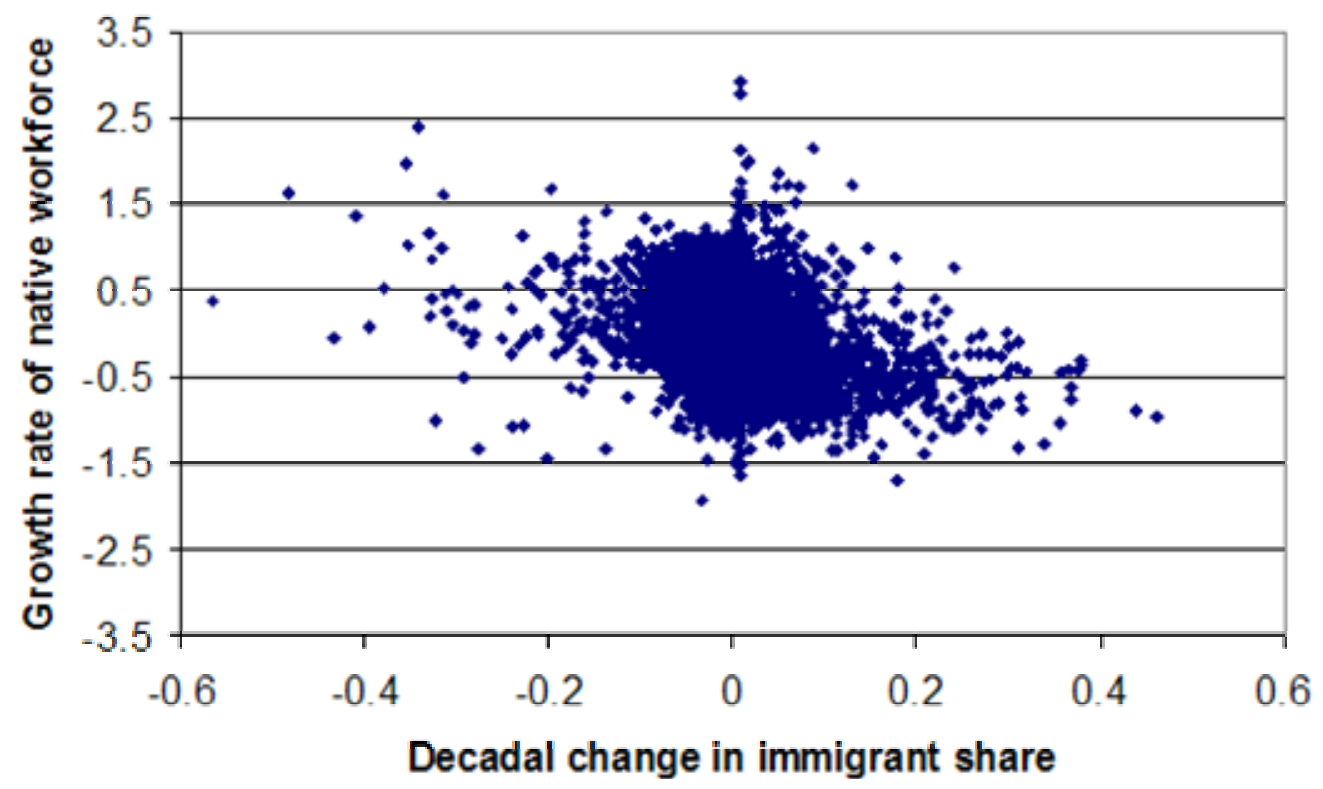

B. Metropolitan area level data

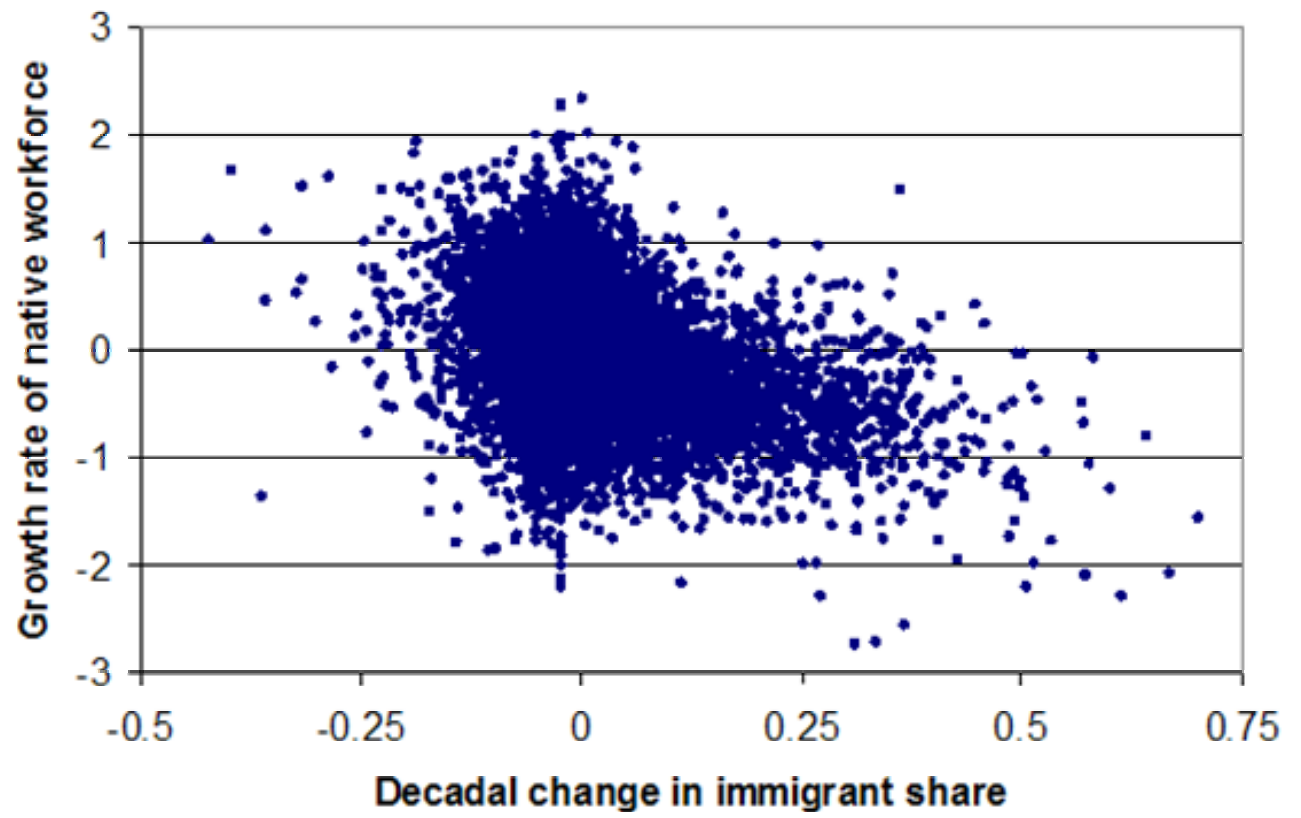

Notes: Each data point represents the decadal change (for the 1960-2000 period in the top panel and the 1980-2000 period in the bottom panel) in the log size of the native workforce and in the immigrant share for a particular skill group in a particular geographic area. Both plots remove decade effects from the data. 
Table 1. Trends in inter-area migration rates of native workers

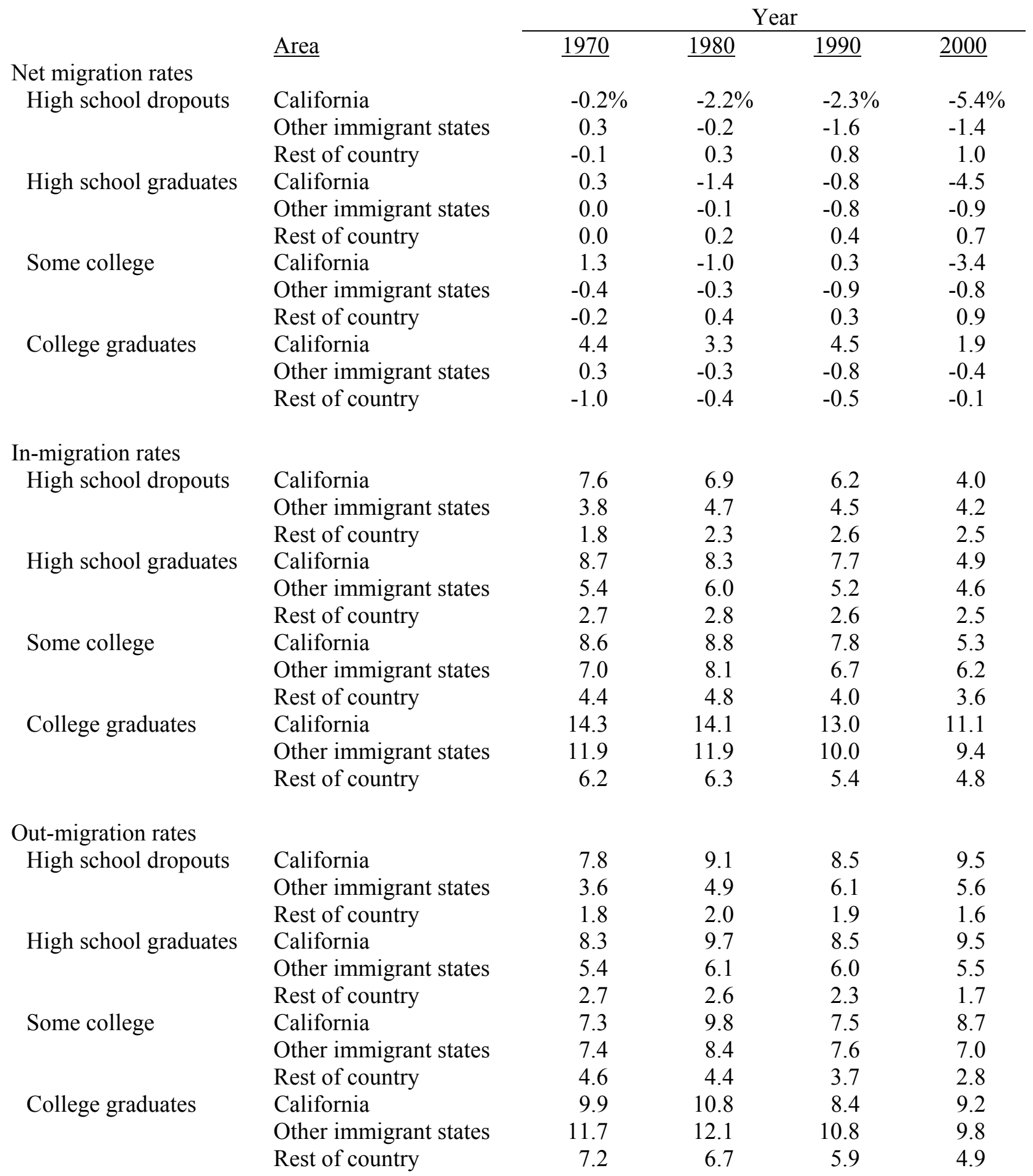

Notes: This table breaks up the country into three distinct areas: California, the other immigrant states, and the rest of the country. The "other immigrant states" include Florida, Illinois, New Jersey, New York, and Texas. A native worker is defined to migrate if he moves from one of these areas to another in the five-year period prior to the Census. 
Table 2. Impact of immigration on log weekly earnings, by geographic definition of the labor market

\begin{tabular}{|c|c|c|c|c|c|c|}
\hline \multirow{3}{*}{$\begin{array}{l}\text { Regression } \\
\text { model: } \\
\text { I. National } \\
\text { (1) }\end{array}$} & \multicolumn{3}{|c|}{ Men } & \multicolumn{3}{|c|}{ Men and women } \\
\hline & $\begin{array}{c}\text { Immigrant } \\
\text { share }\end{array}$ & $\begin{array}{c}\text { Lagged } \\
\text { native } \\
\text { employment }\end{array}$ & $\begin{array}{l}\text { Lagged } \\
\text { native } \\
\text { employment } \\
\text { growth }\end{array}$ & $\begin{array}{c}\text { Immigrant } \\
\text { share }\end{array}$ & $\begin{array}{c}\text { Lagged } \\
\text { native } \\
\text { employment } \\
\end{array}$ & $\begin{array}{l}\text { Lagged } \\
\text { native } \\
\text { employment } \\
\text { growth }\end{array}$ \\
\hline & $\begin{array}{l}-0.533 \\
(0.203)\end{array}$ & --- & --- & $\begin{array}{l}-0.532 \\
(0.189)\end{array}$ & --- & --- \\
\hline \multicolumn{7}{|c|}{ II. Census division } \\
\hline (1) & $\begin{array}{l}-0.274 \\
(0.053)\end{array}$ & --- & --- & $\begin{array}{l}-0.352 \\
(0.061)\end{array}$ & --- & --- \\
\hline (2) & $\begin{array}{l}-0.273 \\
(0.053)\end{array}$ & $\begin{array}{l}-0.043 \\
(0.019)\end{array}$ & --- & $\begin{array}{l}-0.350 \\
(0.061)\end{array}$ & $\begin{array}{l}-0.040 \\
(0.017)\end{array}$ & --- \\
\hline (3) & $\begin{array}{l}-0.274 \\
(0.052)\end{array}$ & --- & $\begin{array}{c}0.048 \\
(0.014)\end{array}$ & $\begin{array}{l}-0.351 \\
(0.062)\end{array}$ & -- & $\begin{array}{c}0.048 \\
(0.015)\end{array}$ \\
\hline
\end{tabular}

III. State

$$
\begin{aligned}
& -0.217 \\
& (0.033) \\
& -0.220 \\
& (0.033) \\
& -0.215
\end{aligned}
$$

$-0.027$

(0.007)

(0.033)

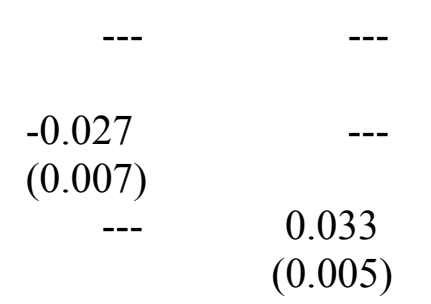

$-0.266$

(0.037)

$-0.271$

$-0.033$

(0.037)

(0.007)

$-0.265$

(0.037)

0.035

(0.006)

IV. Metropolitan area

(1)

(2)

(3)

$\begin{array}{ccc}-0.043 & --- & --- \\ (0.025) & & --- \\ 0.021 & -0.016 & \\ (0.048) & (0.012) & 0.030 \\ 0.048 & --- & (0.008) \\ (0.047) & & \end{array}$

-0.057
$(0.024)$
-0.001
$(0.051)$

0.024

$(0.050)$
$-0.010$

(0.012)

Notes: Standard errors are reported in parentheses and are clustered at the region-skill group level. All regressions are weighted by the size of the sample used to calculate the mean of weekly earnings in the specific region-skill-year cell. The regressions estimated at the national level have 160 observations; the regressions estimated at the region level have 1,440 observations; the regressions estimated at the state level have 8,160 observations $(8,083$ observations when lagged native employment is included); and the regressions estimated at the metropolitan area level have 25,184 $(14,848)$ observations. The regressors in the national-level regression include a vector of skill fixed effects, a vector of time fixed effects, and all possible two-way interactions between a vector of education fixed effects, a vector of experience fixed effects, and a vector of time fixed effects. The regressions presented in the bottom three panels include a vector of skill fixed effects, a vector of (appropriately defined) region fixed effects, a vector of time fixed effects, and all possible two-way interactions among these vectors. 


\section{Table 3. Impact of immigration on the size of the native workforce (Dependent variable $=\log$ of number of natives in workforce)}

\begin{tabular}{|c|c|c|c|c|c|}
\hline \multirow{3}{*}{$\begin{array}{l}\text { Geographic area } \\
\text { and sample } \\
\text { I. Census divisions }\end{array}$} & \multicolumn{5}{|c|}{ Independent variables } \\
\hline & \multirow[t]{2}{*}{$\begin{array}{l}\text { Immigrant } \\
\text { share }\end{array}$} & \multirow{2}{*}{\multicolumn{2}{|c|}{$\begin{array}{l}\text { Lagged } \\
\text { native } \\
\text { employment } \\
\text { growth }\end{array}$}} & \multirow[t]{2}{*}{$\begin{array}{l}\text { Mean log } \\
\text { wage }\end{array}$} & \multirow[t]{2}{*}{$\begin{array}{c}\text { Unemploymer } \\
\underline{\text { rate }}\end{array}$} \\
\hline & & & & & \\
\hline 1. Men & $\begin{array}{l}-0.023 \\
(0.158)\end{array}$ & --- & --- & --- & --- \\
\hline 2. Men & $\begin{array}{c}0.055 \\
(0.121)\end{array}$ & $\begin{array}{c}0.243 \\
(0.042)\end{array}$ & --- & $\begin{array}{c}0.172 \\
(0.116)\end{array}$ & $\begin{array}{l}-1.327 \\
(0.437)\end{array}$ \\
\hline 3. Men & $\begin{array}{c}0.139 \\
(0.147)\end{array}$ & --- & $\begin{array}{c}0.094 \\
(0.031)\end{array}$ & $\begin{array}{c}0.264 \\
(0.158)\end{array}$ & $\begin{array}{l}-1.485 \\
(0.529)\end{array}$ \\
\hline 4. Men and women & $\begin{array}{c}0.106 \\
(0.107)\end{array}$ & $\begin{array}{c}0.306 \\
(0.048)\end{array}$ & --- & $\begin{array}{c}0.072 \\
(0.124)\end{array}$ & $\begin{array}{l}-1.282 \\
(0.402)\end{array}$ \\
\hline 5. Men and women & $\begin{array}{c}0.243 \\
(0.133)\end{array}$ & --- & $\begin{array}{c}0.085 \\
(0.034)\end{array}$ & $\begin{array}{c}0.071 \\
(0.167)\end{array}$ & $\begin{array}{l}-1.816 \\
(0.483)\end{array}$ \\
\hline \multicolumn{6}{|l|}{ II. State } \\
\hline 1. Men & $\begin{array}{l}-0.381 \\
(0.094)\end{array}$ & --- & --- & --- & --- \\
\hline 2. Men & $\begin{array}{l}-0.281 \\
(0.081)\end{array}$ & $\begin{array}{c}0.056 \\
(0.015)\end{array}$ & --- & $\begin{array}{c}0.020 \\
(0.048)\end{array}$ & $\begin{array}{l}-0.376 \\
(0.194)\end{array}$ \\
\hline 3. Men & $\begin{array}{l}-0.273 \\
(0.085)\end{array}$ & --- & $\begin{array}{c}0.037 \\
(0.011)\end{array}$ & $\begin{array}{c}0.117 \\
(0.056)\end{array}$ & $\begin{array}{l}-0.635 \\
(0.208)\end{array}$ \\
\hline 4. Men and women & $\begin{array}{l}-0.300 \\
(0.082)\end{array}$ & $\begin{array}{c}0.106 \\
(0.015)\end{array}$ & --- & $\begin{array}{l}-0.002 \\
(0.047)\end{array}$ & $\begin{array}{l}-0.597 \\
(0.176)\end{array}$ \\
\hline 5. Men and women & $\begin{array}{l}-0.218 \\
(0.083)\end{array}$ & --- & $\begin{array}{c}0.043 \\
(0.011)\end{array}$ & $\begin{array}{c}0.075 \\
(0.054)\end{array}$ & $\begin{array}{l}-0.611 \\
(0.184)\end{array}$ \\
\hline \multicolumn{6}{|l|}{ III. Metropolitan area } \\
\hline 1. Men & $\begin{array}{l}-0.785 \\
(0.060)\end{array}$ & --- & --- & --- & --- \\
\hline 2. Men & $\begin{array}{l}-0.839 \\
(0.091)\end{array}$ & $\begin{array}{l}-0.402 \\
(0.022)\end{array}$ & --- & $\begin{array}{c}0.072 \\
(0.044)\end{array}$ & $\begin{array}{l}-0.307 \\
(0.151)\end{array}$ \\
\hline 3. Men and women & $\begin{array}{l}-0.712 \\
(0.087)\end{array}$ & $\begin{array}{l}-0.365 \\
(0.021)\end{array}$ & --- & $\begin{array}{c}0.057 \\
(0.044)\end{array}$ & $\begin{array}{l}-0.237 \\
(0.125)\end{array}$ \\
\hline
\end{tabular}

Notes: Standard errors are reported in parentheses and are clustered at the region-skill group level. The regressions estimated at the region level have 1,440 observations (1,152 observations when the lagged native employment growth is included); the regressions estimated at the state level have 8,160 $(6,451)$ observations; and the regressions estimated at the metropolitan area level have 25,183 $(14,848)$ observations. All regressions include a vector of skill fixed effects, a vector of (appropriately defined) region fixed effects, a vector of time fixed effects, and all possible two-way interactions among these vectors. 
Table 4. Impact of immigration on migration rates of native workers

Geographic area and specification

I. Census division

1. Net migration rate, men

2. In-migration rate, men

3. Out-migration rate, men

4. Net migration rate, men and women

\begin{tabular}{cccc}
\multicolumn{4}{c}{ Independent variable } \\
$\begin{array}{c}\text { Immigrant } \\
\text { share }\end{array}$ & $\begin{array}{c}\text { Lagged native } \\
\text { employment } \\
\text { growth }\end{array}$ & $\begin{array}{c}\text { Mean log } \\
\text { wage }\end{array}$ & $\begin{array}{c}\text { Unemployment } \\
\text { rate }\end{array}$ \\
-0.076 & 0.060 & 0.147 & -0.048 \\
$(0.046)$ & $(0.023)$ & $(0.056)$ & $(0.206)$ \\
-0.103 & -0.016 & 0.110 & 0.151 \\
$(0.034)$ & $(0.010)$ & $(0.040)$ & $(0.143)$ \\
-0.027 & -0.076 & -0.037 & 0.200 \\
$(0.033)$ & $(0.018)$ & $(0.040)$ & $(0.165)$ \\
-0.082 & 0.066 & 0.071 & 0.059 \\
$(0.042)$ & $(0.019)$ & $(0.051)$ & $(0.189)$
\end{tabular}

II. State

1. Net migration rate, men

$-0.284$

(0.064)

$-0.019$

(0.014)

$-0.151$

$(0.042)$

$-0.055$

$(0.009)$

0.133

(0.049)

$-0.036$

$(0.012)$

$-0.232$

$(0.057)$

$-0.005$

$(0.015)$

\section{$-0.396$}

(0.086)

$-0.084$

$(0.015)$

$-0.114$

(0.057)

$-0.077$

$(0.009)$

0.282

0.007

(0.010)

4. Net migration rate, men and women
(0.062)

$-0.336$

(0.073)
$-0.093$

(0.015)
0.012

(0.070)

0.242

0.018

(0.216)

(0.035)

0.026

0.007

(0.127)

(0.052)

$-0.216$

0.051

(0.171)

(0.058)

$-0.125$

(0.187)

Notes: Standard errors are reported in parentheses and are clustered at the region-skill group level. The regressions estimated at the region level have 1,152 observations; the regressions estimated at the state level have 6,528 observations; and the regressions estimated at the metropolitan area level have 14,848 observations. All regressions include a vector of skill fixed effects, a vector of (appropriately defined) region fixed effects, a vector of time fixed effects, and all possible two-way interactions among these vectors. 


\section{Table 5. Sensitivity of migration results at state level (Coefficient of immigrant share variable)}

1. Baseline (men)

2. Uses 10-year experience groups

3. Excludes workers with less than 5 or more than 35 years of experience

4. Excludes California

5. Excludes high school dropouts

6. Excludes workers with 8 or fewer years of schooling

Dependent variable

\begin{tabular}{cccc}
\hline $\begin{array}{c}\text { Log size of } \\
\text { workforce }\end{array}$ & $\begin{array}{c}\text { Net migration } \\
\text { rate }\end{array}$ & $\begin{array}{c}\text { In-migration } \\
\text { rate }\end{array}$ & $\begin{array}{c}\text { Out-migration } \\
\text { rate }\end{array}$ \\
-0.281 & -0.284 & -0.151 & 0.133 \\
$(0.081)$ & $(0.064)$ & $(0.042)$ & $(0.049)$
\end{tabular}

$-0.331$

$(0.194)$

$-0.244$

$(0.076)$

$-0.105$

(0.045)

0.139

(0.058)

\begin{abstract}
$-0.224$
\end{abstract}
(0.085)

$-0.227$

(0.065)

$-0.116$

(0.044)

0.112

$-0.293$

$-0.262$

(0.071)

$-0.140$

(0.047)

(0.087)

$-0.283$

$(0.218)$

$-0.251$

(0.123)

(0.164)

$-0.896$

(0.119)

$-0.303$

$-0.175$

(0.085)
0.122

(0.050)

0.129

(0.082)

Notes: Standard errors reported in parentheses; all standard errors are clustered by skill and region. The baseline male regressions on the log of the native workforce have 8,160 observations $(6,528$ observations in the migration rate regressions); the regressions using the 10-year experience groupings have 4,045 $(3,264)$ observations; the regressions excluding workers with fewer than 5 or more than 35 years of experience have $6,058(4,896)$ observations; the non-California regressions have 7,906 (6,398) observations; the regressions for workers with at least a high school education have 6,039 (4,892) observations; and the regressions estimated in the sample of workers with at least 9 years of education has 8,043 $(6,522)$ observations. All regressions include a vector of skill fixed effects, a vector of (appropriately defined) region fixed effects, a vector of time fixed effects, all possible twoway interactions among these vectors, and the mean log weekly wage and unemployment rate in the labor market. In addition, the regressions on the log size of the native workforce include the lagged value of the log of the native workforce, while the migration rate regressions include the lagged value of the growth rate of the native workforce. 
Table 6. Synthesis of wage and migration effects

1. Estimate of factor price elasticity (in national

\begin{tabular}{ccc}
$\begin{array}{c}\text { Census } \\
\text { division }\end{array}$ & State & $\begin{array}{c}\text { Metropolitan } \\
\text { area }\end{array}$ \\
\hline-0.389 & -0.389 & -0.389
\end{tabular}
labor market)

2. Estimate of migration effect:

Simple specification: native workforce

Complete specification: native workforce

Complete specification: net migration

$\begin{array}{rrr}-0.017 & -0.278 & -0.573 \\ 0.040 & -0.205 & -0.612 \\ -0.055 & -0.207 & -0.289\end{array}$

3. Predicted estimate of wage elasticity at local level:

Simple specification: native workforce

$\begin{array}{rrr}-0.382 & -0.281 & -0.166 \\ --- & -0.309 & -0.151 \\ -0.368 & -0.308 & -0.277\end{array}$

Complete specification: net migration

$-0.200$

$-0.158$

$-0.031$

Simple specification

$-0.199$

$-0.161$

0.015

Notes: The synthesis is based on the theory-based interpretation of the coefficients reported in Tables 2,3 , and 4 . See the text for details. 